\title{
A prosa em face do discurso poético em Isócrates
}

\author{
Prose in Face of the Poetic Discourse in Isocrates
}

Pedro Ipiranga Jr., Leonardo Gonçalves Fischer

\section{RESUMO}

Uma problemática relevante hoje em dia sobre Isócrates diz respeito à sua relação com a tradição literária de sua época, à utilização de recursos estilísticos na configuração de seus textos, bem como dos procedimentos mais usuais de composição. Propomos neste trabalho fazer um levantamento de passagens que relevem para uma avaliação do status, por assim dizer, literário de sua obra, fazendo um comentário sobre o contexto discursivo em que aparecem e buscando alguns parâmetros comuns sob os quais uma teorização possa ser sugerida. Para tanto, restringiremos a análise àqueles passos em que se apresenta uma comparação ou contraste explícito com a poesia ou com algum poeta em particular. Ainda que apareça na produção isocrateana um termo específico para referenciar prosa (katalogáden, em A Nícocles 7), o mais das vezes utiliza-se nessa acepção a palavra lógos em contraposição textual a discursos com metro. Além disso, através de um quadro comparativo entre as obras comentadas, retomamos as várias passagens nas obras de Isócrates em que prosa e poesia estão inter-relacionadas, a fim de explicitar que havia uma forma recorrente de tratar do estatuto da prosa em correlação com o discurso poético.

Palavras-chave: Isócrates; prosa na Antiguidade; Evágoras; Sobre a troca; A Nícocles.

* Universidade Federal do Paraná - UFPR. 
IPIRANGA JR, P.;

Fischer, L. G.

A prosa em

face do discurso

poético em

Isócrates

An important issue nowadays on Isocrates concerns his relation with the literary tradition of his time, the use of stylistic resources in the configuration of his texts, as well as the more usual procedures of composition. We propose in this work to make a survey of passages that relate to an evaluation of the status, so to speak, literary of his work, commenting on the discursive context in which they appear and seeking some common parameters under which a theorization can be suggested. To that end, we will focus the analysis to those steps in which an explicit comparison or contrast is presented with poetry or with a particular poet. Although a specific term for the reference to prose (katalogáden, in To Nicocles 7) appears in Isocrate production, it is often used in this sense the word logos in textual opposition to speeches with meter. Moreover, through a comparative panel of the works commented on, we return to the various passages in the works of Isocrates in which prose and poetry are interrelated in order to make explicit that there was a recurrent form of dealing with the status of prose in correlation with poetic discourse.

Keywords: Isocrates; Prose in Antiquity; Evagoras; Antidosis; To Nicocles. 
Oegundo Terry Papillon, o fazer literário e composicional de Isócrates está interligado a dois aspectos: a conjuntura política e a dimensão ética e 1 pedagógica que privilegia em todas as suas obras. Tendo assente o poder da tradição poética, ele operaria uma refiguração desta e sua assimilação para a prosa, enfatizando sempre a utilidade daí advinda, cujas vantagens ao discurso seriam, entre outras, as seguintes: o caráter proveitoso, a ênfase no elogio, a faculdade criativa de compor e inventar narrativas, o poder de imortalizar a memória de fatos e pessoas, os vários recursos e procedimentos estilísticos (PAPILLON, 1998, p. 41-43). Ele advoca, a partir daí, uma potencialização do caráter proveitoso do discurso, por parte de Isócrates, que acrescenta a essas vantagens a vinculação com interesses cívicos e com os valores mais reputados para a constituição do cidadão. De certa forma, a comparação e, por vezes, a emulação com as obras de poetas é instrumental para que Isócrates apresente sua agenda política e seu programa pedagógico através de uma concepção de filosofia que abrange deliberação na seara política, treinamento através dos discursos e veiculação de princípios éticos. Suas várias experimentações no campo biográfico constituem o locus por excelência para verificar as funções e possíveis finalidades da correlação buscada com o 
IPIRANGA JR, P.;

Fischer, L. G. A prosa em face do discurso poético em Isócrates discurso poético. Em função disso, comentaremos três obras que apresentam, em maior ou menor medida, elementos ou aspectos do bíos na Antiguidade, a saber, $A$ Nícocles, Sobre a troca ou Antidosis e Evágoras. Ao fim, apresentamos um quadro comparativo para o cotejo de passagens dessas obras.

\section{A Nícocles: o aspecto gnômico face ao estético}

O discurso A Nícocles, um dos chamados Discursos Cipriotas de Isócrates, consiste em uma longa exortação ao jovem príncipe de Chipre e discípulo do orador. Nesse discurso, constituído por diversas recomendações e máximas proverbiais dirigidas a Nícocles na forma de conselho, Isócrates afirma que não cabe a um discurso dessa natureza buscar a inovação artística nem se pode esperar que ele agrade ao público (A Nícocles, 41-42). Em seguida, ele cita os exemplos de Hesíodo, Teógnis e Focílides, poetas gnômicos reconhecidos como úteis a todos em razão de seus conselhos, mas que não são do agrado da maioria da população, que prefere as piores comédias (43-44). A partir disso, Isócrates conclui que, para se escrever algo que agrade ao público, se deve abrir mão da utilidade, mencionando como exemplos desse procedimento Homero e os trágicos, que, ao recorrerem aos expedientes do fabuloso e do conflito, são considerados mais agradáveis por todos (48-49). Aqui, portanto, a fala do orador aponta para uma impermeabilidade entre o útil e o agradável nos discursos, sugerindo que o bom aconselhamento assuma inevitavelmente uma forma árida em suas formulações. O discurso, dessa forma, é do tipo parenético, uma vez que a persona de Isócrates, na figura do narrador, dirige conselhos e preceitos ao jovem, no sentido de melhor administrar seu reino e governar sobre seus súditos. Mas também, atrelado a isso, procede à elaboração de um modo de vida apropriado ao governante, ao qual não pode faltar um treino contínuo nos discursos. Vejamos o passo abaixo:

Julgo que seria a mais bela dádiva, a mais proveitosa e a mais apropriada para te dar e para tu receberes, se conseguisse determinar para quais ocupações te inclinando e de quais tarefas te afastando poderias administrar da melhor maneira possível a tua cidade e a tua realeza. $\mathrm{O}$ cidadão comum conta com muito que contribui para a sua educação: antes de tudo, ter uma vida sem luxos e ser forçado a deliberar dia a dia acerca de sua própria sobrevivência. Depois, as leis que balizam a vida política de cada um, a liberdade de expressão e a possibilidade de, por causa dos erros que cometeram aqui e ali, a olhos vistos reprovar aos amigos e atacar às claras os inimigos. Por fim, alguns dos antigos poetas lhe legaram conjuntos de conselhos sobre como viver a contento

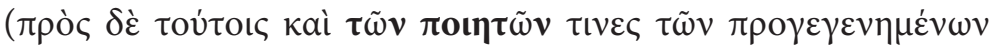

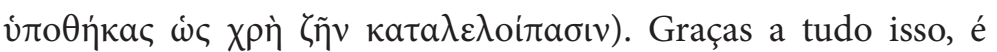

Revista Letras,

Curitiba, UFPR,

n. 97, pp. 8-37,

jan./jun. 2018.

ISSN 2236-0999

(versão eletrônica) 
verossímil que o cidadão comum esteja melhor. (A Nícocles, 2-3; trad. de Julio de Figueiredo Lopes Rego, grifos nossos)

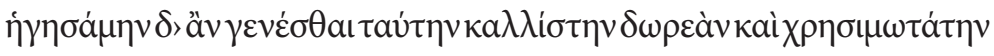

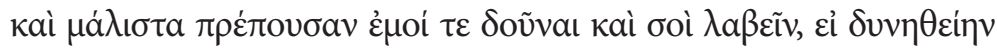

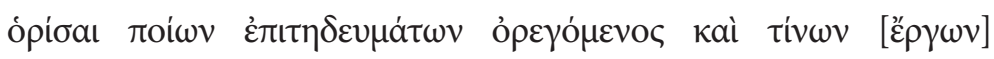

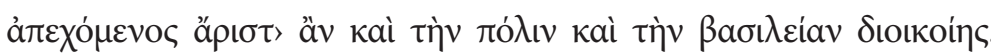

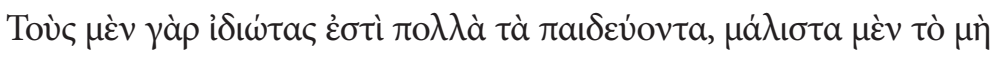

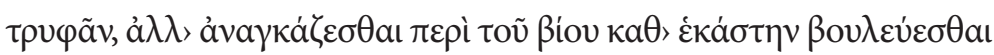

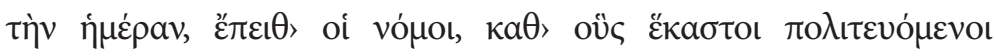

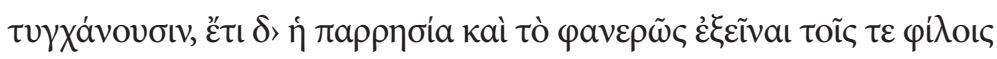

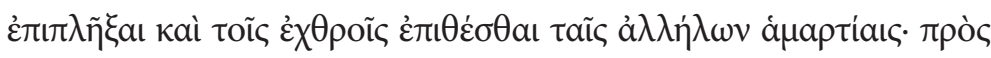

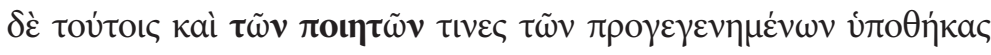

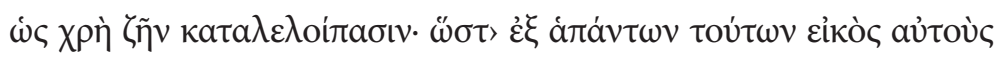
$\beta \varepsilon \lambda \tau i$ ov $\gamma^{\prime} \gamma v \varepsilon \sigma \theta a$.

O presente oferecido a Nícocles é o próprio discurso de Isócrates, o qual possui um escopo, a princípio, predominantemente político: administrar a cidade e a realeza. Não obstante, há de se partir de uma reflexão sobre a vida dos particulares, sobre a paideia do homem comum. Em outras passagens da obra, essa conexão entre as esferas pública e privada é melhor explicitada pelo autor. Aqui cabe chamar a atenção para o papel primordial dos poetas tanto na educação, quanto na forma de conduzir a vida. Assim, de forma bem sutil e introdutória, parece haver uma semelhança buscada entre as obras dos poetas e o discurso isocrateano em vista do conteúdo parenético, admoestador e exortativo. Com efeito, em escritos como $A$ Nícocles, Evágoras e Nícocles, é a figura do soberano que se mostra como paradigma moral. O que se propõe como teleologia moral está ligado à timé e à dóxa, ou seja, ter uma boa reputação entre os concidadãos. A elaboração do trabalho ético atrela-se também aos exercícios de aprendizagem, de memorização e a todos aqueles que correspondem à epiméleia, ao cultivo e ao treinamento da mente e do espírito ( $A$ Nícocles, 27-28).

Não obstante, ainda que essa prevalência do parenético em detrimento da dimensão estética seja advogada e aí desenvolvida, essa opinião, contudo, não parece se sustentar no restante da obra de Isócrates, nem refletir sua própria prática de ensino. Desde o discurso programático da fundação de sua escola, Contra os Sofistas, Isócrates expressa uma considerável atenção ao exercício composicional, reiterando a necessidade de se ornar convenientemente os discursos com as ideias e de dispor com bom ritmo e harmoniosamente as palavras (16). Ainda em uma obra posterior, Sobre a troca, o orador se inclui entre aqueles que "preferem escrever discursos não sobre assuntos particulares, mas sim discursos helênicos, políticos e panegíricos, os quais todos diriam ser mais semelhantes às obras feitas com metro e ritmo do que às que são faladas nos tribunais". Nesses discursos, segundo Isócrates, seria possível encontrar "um estilo poético e variado", e "ideias mais fortes e novas", e tais discursos seriam capazes de fazer com que 
IPIRANGA JR, P.;

Fischer, L. G. A prosa em face do discurso poético em Isócrates

Revista Letras, Curitiba, UfPR, n. 97 , pp. 8-37, jan./jun. 2018. ISSN 2236-0999 (versão eletrônica) seus autores fossem estimados por mais sábios que aqueles que meramente falam bem nos tribunais (Sobre a troca, 46-47).

Se voltarmos às alegações presentes em $A$ Nícocles à luz dessas outras reflexões de Isócrates, podemos interpretar que a cisão entre útil e agradável opera como argumento específico dessa obra. Composta em grande medida pela mera sequência de máximas proverbiais em uma sucessão de períodos curtos e desconectados entre si, essa obra destoa do estilo típico de Isócrates, marcado por períodos longos cuidadosamente articulados e elaborados com paralelismos ${ }^{1}$. Quando Isócrates afirma que um discurso sobre costumes deve não buscar novidades, mas sim reunir o maior número de máximas de outros homens e os dispor do melhor modo, ele está simplesmente explicitando o processo de composição desse texto em particular. Evidência disso é o reconhecimento do próprio orador, em Sobre a Troca 67-69, de que seu discurso para Nícocles difere em estilo de suas outras obras. Desse modo, o argumento da cisão entre ensinar e agradar opera como uma justificativa retórica da estrutura desse mesmo discurso.

Ademais, mesmo em A Nícocles, ele esboça sua expectativa ante a avaliação da obra pelo público, pondo-se no mesmo patamar dos poetas em relação às suas composições em metros:

Se então tal presente, uma vez confeccionado, será digno do assunto, é difícil saber desde o início; com efeito, muitas das composições poéticas com metro e das composições escritas em prosa (tôn metà métrou poiemáton kaì tôn katalogáden syngrammáton), ainda estando no pensamento dos compositores, proporcionavam grandes expectativas, mas, uma vez terminadas e apresentadas aos outros, alcançaram uma reputação bem inferior ao que se esperava.

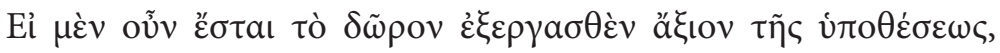

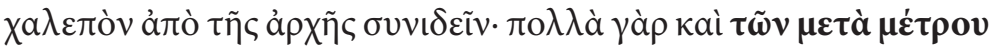

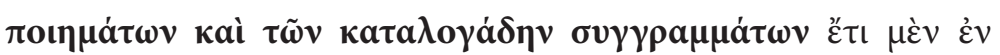

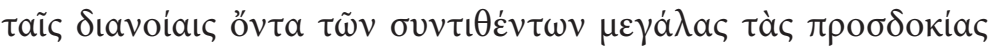

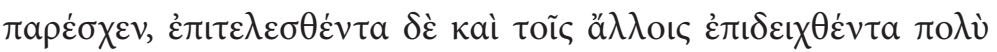

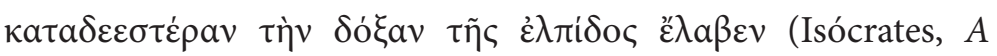
Nícocles, 7; tradução e gritos nossos).

A passagem é importante. Aparece aqui um termo mais específico para prosa: katalogáden. A despeito disso, o que determina essa especificação vem, antes de tudo, por intermédio da relação explícita feita com o discurso poético, que é o procedimento mais usual nas diversas ocasiões. Há, por conseguinte, um paralelismo e contraste entre metà métrou e katalogáden (com metro e em prosa), de um lado, e entre tôn poiemáton e tôn syngrammáton (dos poemas e das composições escritas),

1 Cf. USHER, 1973. 
de outro. Ao contrário de Platão ${ }^{2}$, Isócrates não deixa de valorizar o registro escrito das composições em prosa e o efeito e o mérito de suas obras já escritas. Vislumbra-se aqui, de maneira esquemática, o processo de composição, recepção e transmissão: o projeto enquanto esquema mental, a configuração literária, a apresentação diante do público e a avaliação (e, por conseguinte, a divulgação) daí advinda.

De maneira mais restritiva, em outro passo, ele advoga, como foi dito, uma aproximação com a poesia dita gnômica (Hesíodo, Teógnis, Focílides), a qual teria uma finalidade bem distinta da poesia de Homero e da tragédia, pois estas se disporiam a agradar a multidão, enquanto aquela teria um intuito pedagógico e aconselhativo, da mesma forma que sua própria obra de caráter protréptico, concernente à educação de um soberano. Eis o passo correspondente:

Dado que para mim está claro que todos julgam de muitíssima serventia os conselhos de poetas e prosadores (advindos de poemas e de composições em prosa), os homens, entretanto, não os escutam com prazer e reagem como quem é repreendido e, muito embora elogiem esses autores, a bem da verdade, preferem estar junto de quem cometeu os mesmos erros que cometeram, e não daqueles que das falhas os afastam. A poesia de Hesíodo, Teógnis e Focílides poderia ser dada como prova disso: dizem, com efeito, que esses são os melhores conselheiros para a vida dos homens, mas, conquanto afirmem isso, preferem se ocupar antes com os seus próprios disparates do que com os conselhos deles. Se alguém selecionasse as chamadas máximas dos poetas eminentes nas quais mais se esforçaram, ao fim comportar-se-iam do mesmo modo diante delas: para essas pessoas, seria mais prazeroso escutar a pior comédia do que as obras compostas da maneira mais engenhosa (artística). (A Nícocles, 42-44; trad. de Julio de Figueiredo Lopes Rego, grifos nossos)

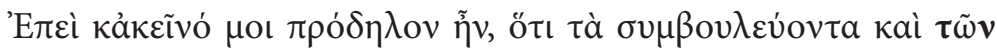

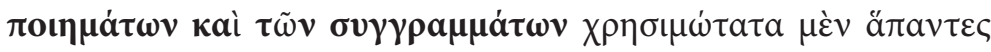

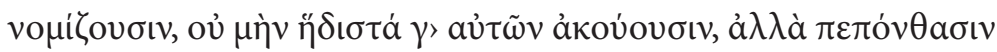

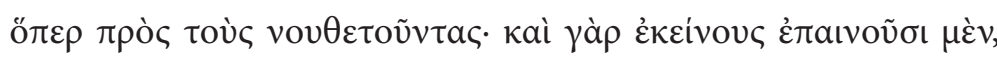

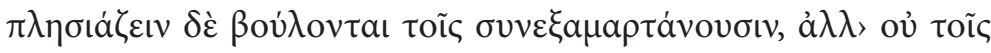

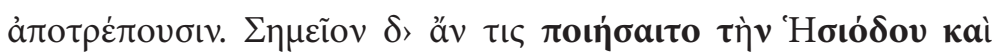

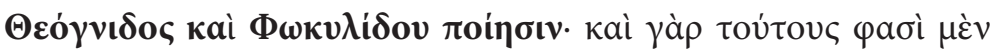

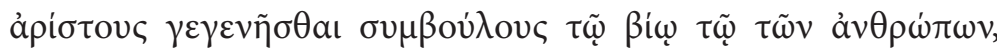

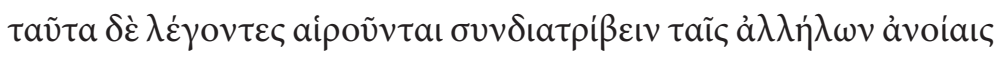

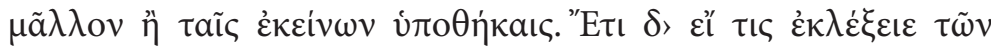

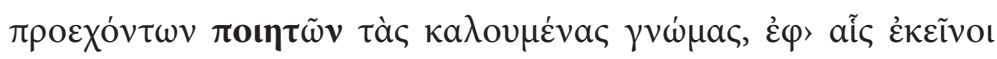

2 Cf. IPIRANGA JÚNIOR, 2016; MOUZE, 2011; SZLEZÁK, 1997. 
IPIRANGA JR, P.;

FISCHER, L. G.

A prosa em

face do discurso

poético em

Isócrates

Revista Letras,

Curitiba, UFPR,

n. 97 , pp. 8-37,

jan./jun. 2018.

ISSN 2236-0999

(versão eletrônica)

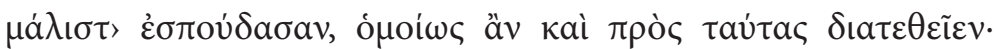

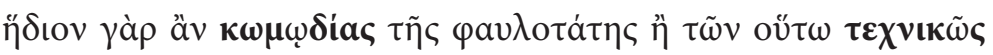

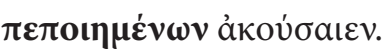

Aqui a contraposiçãoéfeita entre os termos tôn poiemáton e tôn syngrammáton (dos poemas e das composições escritas), prescindindo-se da especificação anterior metà métrou e katalogáden (com metro x em prosa) por já estar pressuposta. Entre as duas passagens anteriores, estão inseridos uma enumeração de conselhos e preceitos dirigidos a alguém que queira bem governar; interessante que aqui são visados os sofistas vis-a-vis os poetas, como citados no parágrafo $13^{3}$. Embora, em vista da finalidade do discurso, como foi antes visto, a poesia gnômica seja valorizada em detrimento da épica e do drama, o discurso poético em si se mostra como instrumental para indicar similaridades e uma certa paridade com certa espécie de prosa que, em certo grau, é exemplificada a partir do próprio discurso isocrateano. Em Sobre a troca, como dito anteriormente, Isócrates, ao contrário, alia ao benefício do caráter aconselhativo e parenético o prazer advindo do desfrute de uma obra composta artisticamente. Aqui, todavia, em A Nícocles, o prazer dos ouvintes e espectadores é contraposto ao caráter de utilidade de composições em prosa e dos poemas gnômicos ${ }^{4}$. Nessa perspectiva, ele vai contrapor o útil ao fabuloso, mas o

3 Cf. a passagem: (...) tem em mente que a educação e o empenho podem melhorar a nossa natureza e, dentre os que estiverem mais próximos de ti, aproxima-te dos mais prudentes. Os demais, se puderes, manda vir até ti. Julga que não deves ignorar nenhum dos poetas célebres, tampouco nenhum dos sofistas, mas, pelo contrário, sê espectador (ouvinte) dos primeiros e um estudante

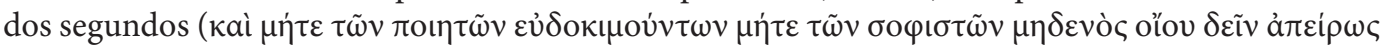

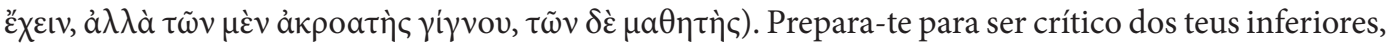
mas um oponente dos teus superiores. Mediante tais atividades rapidamente te tornarás tal como imaginamos ser um rei que governa a cidade com retidão e que a administra com adequação. ( $A$ Nícocles, 12-13; trad. de Julio de Figueiredo Lopes Rego, grifos nossos).

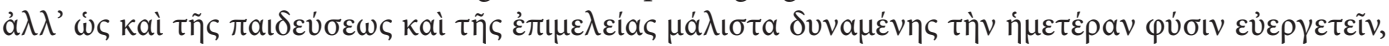

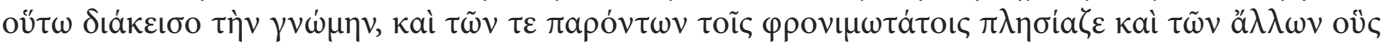

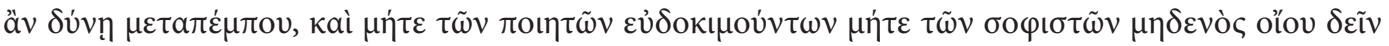

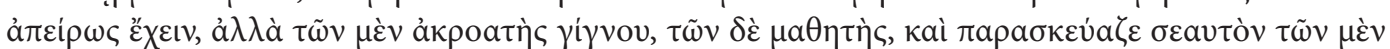

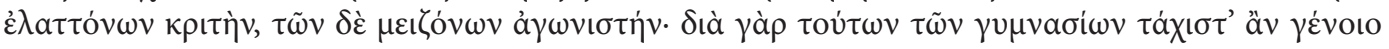

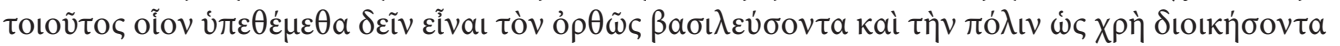

4 Cf. a passagem: "Por causa disso está patente que quem desejar compor ou escrever algo atraente para a massa deve descartar os discursos mais proveitosos e selecionar os mais fabulosos, pois lhes agrada tanto ouvir tais coisas quanto assistir a combates e contendas. Por isso, também a poesia de Homero e dos primeiros inventores da tragédia é admirável: ao analisar a natureza humana, utilizaram ambas as formas em seus poemas (em sua poesia). Um narrou as fábulas dos conflitos e contendas dos semideuses, os outros, por sua vez, transformaram as fábulas em conflitos e feitos que não só são escutados, mas também vistos por nós. Portanto, partindo de tais exemplos, está demonstrado que os que anseiam seduzir os ouvintes devem se afastar da reflexão e do conselho, e, em vez disso, falar daquelas coisas com as quais a multidão terá prazer. (A Nícocles, 48-49; trad. de

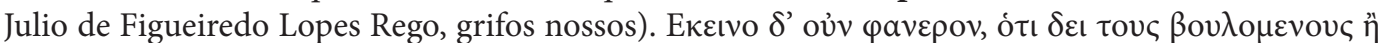

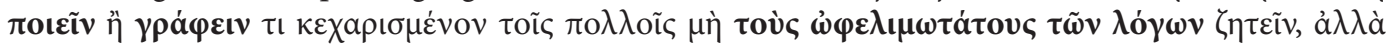

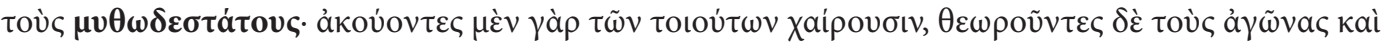

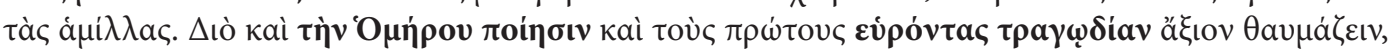

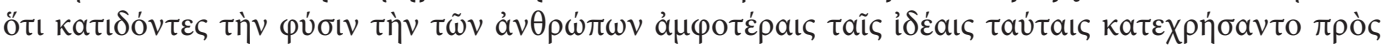

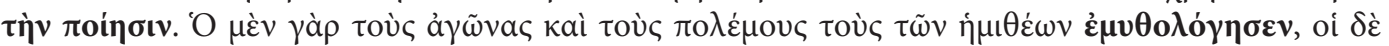

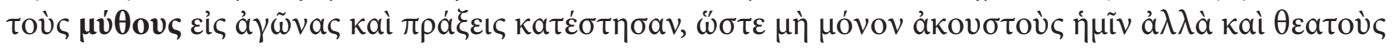

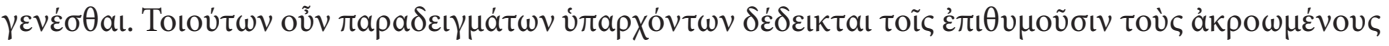

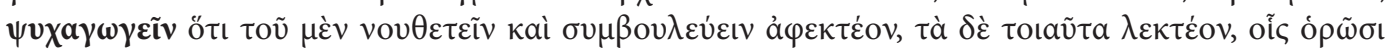

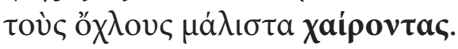


paralelismo empregado então no final da obra, compor ou escrever (poieîn/gráfein), evoca as expressões anteriores mais completas, testificando a perspectiva visada no presente estudo de que as referências à poesia ou aos poetas enquadradas num contexto de correlação com composições em prosa implicam uma certa teorização sobre o discurso em prosa.

\section{Sobre a troca: o programa pedagógico de Isócrates em correlação com a poesia}

Na obra Sobre a troca, Isócrates forja e inventa um processo de acusação contra ele próprio como uma forma de falar de si e, de certo modo, transformar a imagem de si formada pelos outros. Com efeito, em um processo anterior movido contra ele, o qual, segundo a letra da lei, era passível de ocasionar uma troca de bens (antídosis), fora ele obrigado a arcar com uma 'liturgia', isto é, custear com os próprios recursos uma obra pública, no caso, a manutenção de um navio. Esse processo, por conseguinte, parece tê-lo induzido a fazer uma defesa pessoal neste escrito Sobre a troca, como se fosse composto para um tribunal, no intuito de, pretensamente, corrigir a imagem de si junto a seus concidadãos. É, assim, um pretexto discursivo para falar de si mesmo, forjando para isso uma situação de julgamento, em que era possível fazer uma análise mais perspicaz e aprofundada sobre si mesmo e uma retrospectiva das próprias obras.

E lede a apologia que foi fabricada, por um lado, como se tivesse sido escrita acerca de um julgamento e, por outro, como que requeresse mostrar a verdade acerca de mim mesmo, tanto para fazer com que os que me desconhecem venham a me conhecer, quanto para afligir os que me invejam ainda mais por sua afecção, pois maior justiça eu não conseguiria alcançar junto a eles. (ISÓCRATES, Sobre a troca, 13, tradução nossa)

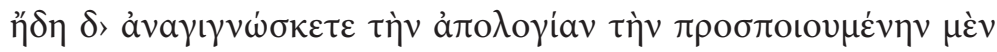

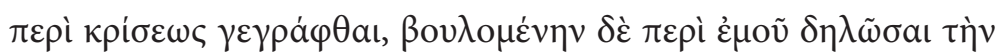

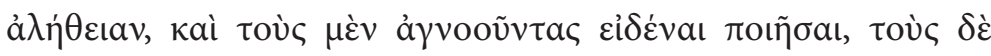

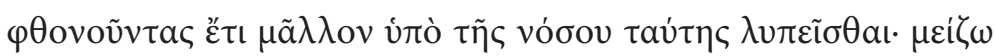

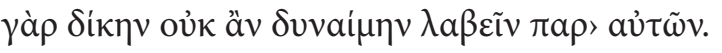

De maneira esquemática, há dois eixos para se pensar a finalidade do relato: a situação de julgamento e o espaço de constituição do si mesmo, a partir de que se verifica a estreita relação entre a formação do foro discursivo do si mesmo e a cenografia dramática em que ele se forma, que é justamente um processo de julgamento diante de um tribunal. Cabe chamar a atenção para o caráter de inovação que Isócrates reivindica para ele e uma das formas de marcar essa alteridade é a comparação com a poesia, sendo que aqui não se restringe ao conteúdo ou ao propósito puramente pedagógico de seus 
IPIRANGA JR, P.;

FISCHER, L. G.

A prosa em

face do discurso

poético em

Isócrates

discursos, embora isso também seja levado em conta. Ele passa em revista os vários tipos de discurso: encômio x apologia, inicialmente 5 .

Não obstante, ele chega a declarar que tal obra não se conforma estreitamente com os discursos que são apresentados nos processos jurídicos (agónes) ou em exibições públicas de aparato (epideíxeis), ou seja, de certo modo, extrapola formal e funcionalmente uma apologia ou um encômio. Proclamando a novidade (kainóteta) e a diferença (diaphorán) de seu próprio discurso em relação a estes últimos, ele se arrisca numa concepção de gênero heteróclita, escolhendo critérios outros para sua obra, o que a situa fora da classificação aristotélica dos tipos discursivos retóricos. Segundo ele, enquanto partes do seu discurso seriam condizentes com o modo do tribunal, outras partes aí não se enquadrariam, pois seriam expostas com coragem e liberdade de expressão acerca da filosofia (perì dè philosophías peparrhesasména). Isócrates esclarece que aí a filosofia tem um caráter pedagógico, ou seja, destina-se aos mais jovens que se dedicam às ciências e à educação; por isso lança mão de extratos de seus escritos anteriores (19). A obra que escreve, prossegue ele, não é simples e impõe uma grande dificuldade pela quantidade e variedade de temas e estilos. Nessa perspectiva, seu discurso é misto (óntos miktoû toû lógou), o que demandaria um maior cuidado e maior atenção na leitura e na audição, em que o leitor deve buscar nuanças diferenciadas para as várias partes, a fim de não afligir e cansar os ouvintes presentes (cf. OBER, 2004, p. 32).

Do lado do conteúdo, ele mistura e costura partes de outros discursos: isso parece compor uma espécie de fundo autobiográfico do escritor, permitindo uma avaliação diacrônica e retrospectiva de suas obras. Do ponto de vista da recepção, a obra pressupõe tanto o público do tribunal (o destinatário seria a assistência presente a um processo judicial, embora aqui esse tipo de público seja apenas imaginado, pois o julgamento é uma invenção), quanto um público de escola (que acolherá um texto cujas partes vão ser lidas, estudadas e repetidas) ${ }^{6}$; pressupõe, assim, um ouvinte, um leitor e, mais concretamente, a audiência de uma leitura pública. Da perspectiva do gênero, mistura formas retóricas, o dicânico (apologia) e o epidítico (encômio), com as formas pedagógicas de escritos de tom moral e filosófico. Todavia, o que se torna mais distintivo na obra é a sua remessa à primeira pessoa, o seu centramento em volta de um narrador em primeira pessoa, o qual vem a ser o princípio de unidade de um discurso assim longo e variado.

5 Elogiar a si mesmo, segundo Isócrates, além de não ser agradável e não deixar de suscitar a inveja, não permitiria que se abarcassem todos os assuntos e perspectivas sobre as quais se dispunha a discorrer (Sobre a troca, 8). Assim, de uma maneira genérica, concluir-se-ia que o encômio pode ser um bom modo de falar de outrem, mas que a melhor forma de falar de si é fazer uma apologia de si mesmo. Para isso, por um lado, como dito anteriormente, ele imagina uma luta judicial que põe em perigo sua vida, levada a cabo por um sicofanta que faz uso dos mesmos argumentos mentirosos utilizados no processo anterior de antídosis (troca de encargos/bens); por outro lado, coloca-se na posição de acusado que deve fazer sua defesa seguindo, de maneira genérica, pelo menos, procedimentos do discurso apologético de então, mas, ao mesmo tempo, fazendo um relato sobre o próprio bíos e sobre suas obras.

6 Segundo Terry Papillon, Isócrates formulava discursos encomiásticos tanto para o ensino dentro

Revista Letras, de sua escola, quanto para fazer a sua publicidade junto à comunidade (PAPILLON, 2001, p. 75).

Curitiba, UFPR,

n. 97, pp. 8-37,

jan./jun. 2018.

ISSN 2236-0999

(versão eletrônica) 
Dizer que sua obra é de um gênero misto parece evidenciar a dificuldade e a hesitação de Isócrates em classificá-la. Ele cita, a propósito, alguns tipos de prosadores: aqueles que passam a vida explorando as vidas dos semideuses, os que meditam filosoficamente sobre os poetas, os que querem reunir os fatos e as ações ocorridas nas guerras, os que se ocupam acerca de questões e respostas, ou seja, que fazem antilogias. Vejamos o passo correspondente:

Primeiramente, então, é preciso vocês perceberem isso: que os diferentes tipos de discurso (em prosa) não são menos numerosos do que aqueles dos poemas metrificados. Com efeito, certos prosadores gastaram sua vida investigando as genealogias dos deuses, outros comentaram filosoficamente sobre os poetas, outros quiseram recolher e reunir as ações ocorridas nas guerras e outros mais se ocuparam do gênero relativo a perguntas e respostas, os versados no método contestativo. Seria não pequena tarefa se eu tentasse enumerar todas as espécies de discursos; fazendo menção, contudo, àquela que então me é conveniente, deixarei de lado as outras. Com efeito, existem aqueles que, sem serem desprovidos de experiência nos tipos de prosa anteriormente ditos, preferiram escrever discursos, não sobre os contratos efetuados entre vocês, mas discursos de caráter helênico, político e panegírico, discursos que todos diriam ser mais semelhantes àquelas composições acompanhadas de música e ritmos do que àqueles enunciados nos tribunais. Estes discursos inclusive através de uma dicção/estilo mais poética e variegada apresentam as ações, e buscam se utilizar de argumentos mais pomposos e inovadores, ademais organizam o discurso como um todo através de diversas formas/estruturas notáveis e numerosas. Com esses tipos de prosadores, todos os ouvintes se alegram não menos do que com os poetizadores em obras com metro, e muitos inclusive desejam se tornar deles discípulos, considerando que os mais notáveis entre eles sejam muito mais sábios, melhores e mais capazes de trazer benefícios do que aqueles que fazem bons discursos para os pleitos. (Isócrates, Sobre a troca, 45-47; tradução nossa)

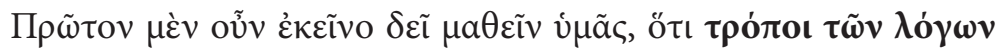

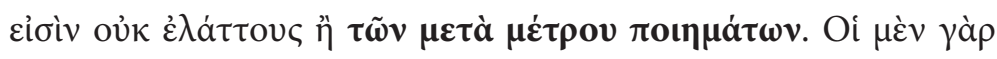

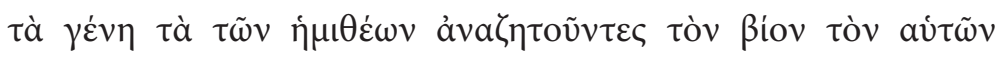

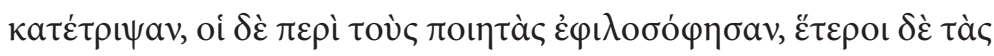

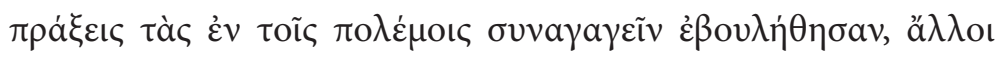

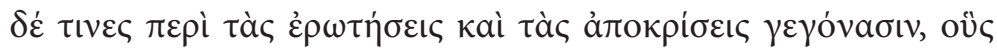

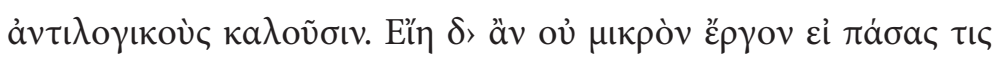

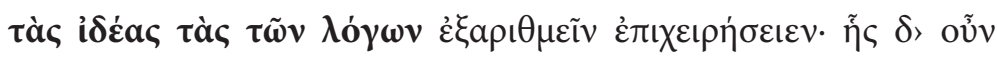

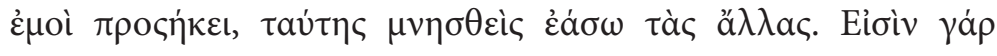


IPIRANGA JR, P.;

FISCHER, L. G. A prosa em face do discurso poético em Isócrates

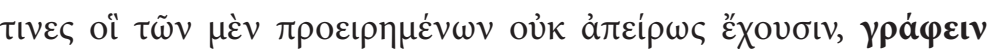

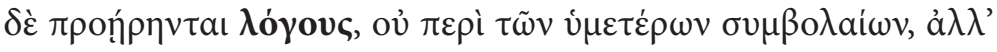

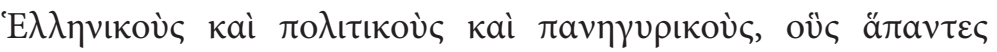

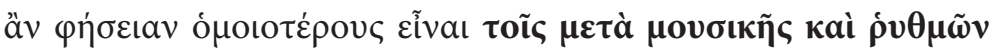

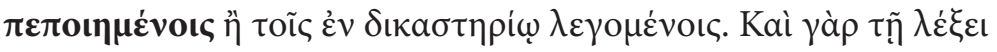

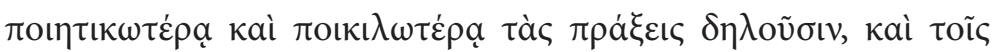

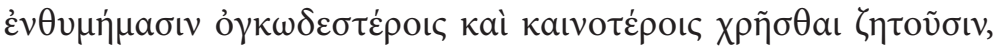

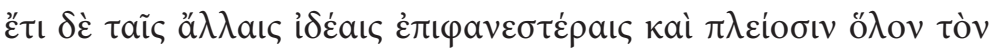

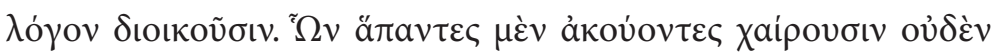

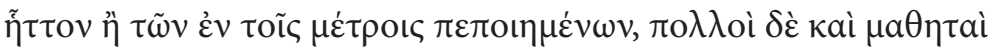

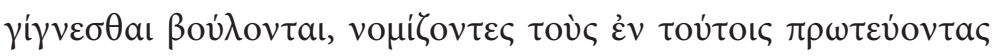

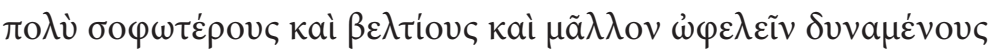

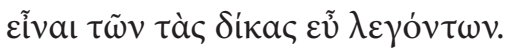

Nessa enumeração, existe algum tipo de taxonomia que se define a partir de seus agentes: geneálogos, filólogos ou sofistas como Eveno de Paros ${ }^{7}$, historiadores e dialéticos ou erísticos. A ênfase recai no fato de que os que utilizam determinados modos de discursos em prosa (trópoi tôn lógon) passam a vida dedicados a certas ocupações e seu modo de vida distingue e caracteriza seus discursos/lógoi. Por conseguinte, o bios, ou melhor, a diatribé, o passar a vida num mesmo labor, é para ele o agenciador distintivo numa concepção de gênero. De qualquer modo, na sequência, ele distingue seu próprio tipo de prosa dos anteriormente mencionados; para isso fornece, sem embargo, dois critérios para balizar a construção do estatuto de sua obra: um positivo e outro negativo. O primeiro diz respeito à aproximação e à comparação com o discurso propriamente considerado poético. Ele explica que prefere escrever (gráphein) discursos de caráter helênico, de tom panegírico e relativos aos interesses da pólis; esclarece, em seguida, que tais composições mais se assemelham às composições acompanhadas de música e ritmos (toîs metà mousikês kaì rhythmôn pepoieménois) (46). No âmbito da produção, seus discursos mostrariam as ações através de uma elocução poeticamente mais apurada e mais diversificada; os pensamentos aí empregados devem ser moralmente convenientes e mostrarem inovação, bem como as figuras ou temas necessitam ser surpreendentes e numerosos. No âmbito da recepção, os ouvintes de tais composições não se alegram (khaírousin) menos do que em relação às obras compostas em metros (tôn en toîs métrois pepoieménon), e esse prazer suscita o desejo dos jovens de aprender a se tornarem melhores, mais sábios e mais proveitosos para a pólis, caso venham a ser aprendizes de tal gênero de discursos $(47)^{8}$.

7 Para o interesse de Isócrates pela poesia em correlação com Platão, Eveno de Paros e outros autores contemporâneos, cf. REGO, 2010, p. 4-5; PLATÃO, Fédon, 267a.

8 Embora essa espécie de teorização esteja dispersa e seja apresentada, algumas vezes, de modo pouco preciso, nesse ponto do relato ele fornece vários elementos para se depreender da produção e da recepção parâmetros definidores do estatuto de sua obra, enquanto tangente ao discurso poético. Não há, é claro, uma mímesis da ação, mas sim a composição de ações, sentimentos e idéias

Revista Letras, segundo um estilo poético e visando a um prazer estético (Cf. MATHIEU, 1950, p. 99-101); todavia,

Curitiba, UfPR,

n. 97, pp. 8-37,

jan./jun. 2018.

ISSN 2236-0999

(versão eletrônica) 
A princípio, então, a caracterização que Isócrates faz de seu logos como philosophía apresenta três eixos de determinação: um concernente às questões que visam aos benefícios e à contribuição dos cidadãos a Atenas; um outro ligado à conveniência e à formação moral que é inerente a uma paidéia pelos discursos; e, enfim, o eixo que vincula a prosa isocrática ao discurso poético, em sua configuração composicional e em seus efeitos, que concernem ao prazer visado entre ouvintes e leitores. Tais discursos, segundo ele compostos a partir da filosofia, possuem uma determinada dýnamis, um poder, uma efetividade. A força dos discursos da filosofia não está restritamente ligada ao poder de persuasão, uma vez que ele faz aqui justamente uma contraposição com o discurso dicânico, cujo objetivo se limitaria a isso. Esta dýnamis seria referente, de certa forma, ao poder de um discurso em prosa composto poeticamente e dotado de uma efetividade estético-cognitiva, passível de suscitar prazer e uma disposição para o saber. Aliás, Isócrates expõe isso segundo uma equação tripartida, cujos termos se iluminam e determinam uns aos outros: ou da sua dýnamis ou da sua filosofia ou da sua diatribé ele propõe falar a verdade (tèn aléheian) (50).

O critério negativo, por seu turno, utilizado para definir parâmetros para o lógos isocrático, assenta-se nas várias antinomias em que ele contrapõe o seu discurso ao representado pelo dicânico e, ao mesmo tempo, ao modo de vida e ao comportamento dos que lidam com processos no tribunal'9. A contraposição mais recorrente se dá nestes termos: os que preparam discursos para as ações judiciais se envolvem em contratos e negócios de âmbito privado, enquanto aqueles que compõem discursos segundo as prescrições e os princípios de Isócrates se voltam para os assuntos públicos de grande importância e, de algum modo, vantajosos para a cidade ${ }^{10}$. Assim, a apologia é uma defesa do seu bíos, o que não deixa de ser a defesa de sua ocupação (diatribé), de sua philosophía.

Segundo Schiappa, Isócrates não queria ser definido como um rhétor, detentor de uma habilidade para a persuasão como um fim em si mesma (SCHIAPPA, 1999, p. 170 ). A dýnamis da filosofia, além de uma efetividade marcadamente poética, tem de revelar probidade, uma qualidade moral elevada daqueles que compõem discursos, assentada na dóxa, na reputação do indivíduo entre os seus concidadãos. De uma forma ou de outra, ele tem de demonstrar que é um cidadão kalòs kagathós no contexto da pólis, ou melhor, que parece ser, que tem uma tal reputação diante dos demais. Assim, areté, dóxa e timé são concepções bastante imbricadas na prosa e na teorização de Isócrates. Segundo Alexiou, a busca da boa fama constitui-se, nesse escritor, em relação à concepção de pístis (prova); dessa forma, a boa disposição dos ouvintes para com o orador seria o requisito mais importante para o convencimento,

mantém-se um princípio ético como parâmetro de composição determinante, assim como um engajamento temático em relação aos assuntos da pólis.

9 Para um contraste entre discursos para tribunais e discursos feitos fora do contexto do tribunal, cf. PAPILLON, 2001, p. 89; cf. POULAKOS, 1997, p. 9-25.

10 Cf. ISÓCRATES, Sobre a troca, 41, 46. Ao distinguir a sua ocupação daquela relativa aos que ele chama de sicofantas, o principal argumento gira em torno do fato de Isócrates ter muitos discípulos, enquanto os seus acusadores não possuírem nenhum. 
IPIRANGA JR, P.;

Fischer, L. G. A prosa em face do discurso poético em Isócrates

a partir do que a habilidade nos discursos estaria necessariamente vinculada "à inserção global do cidadão dentro da comunidade, à constituição do kalòs kagathós em todas as manifestações do corpo social" (ALEXIOU,1996, p.70). Embora haja, certamente, a conjunção de areté e dóxa, de eînai e dokeîn na argumentação de Isócrates, como afirma Alexiou, o fato de se mostrar epieikés, virtuoso e honesto pelo próprio bíos, não é suficiente para o persuadir. É isso que Isócrates explicita quando declara que tantos homens foram mais importantes e mais dignos de valor do que aqueles celebrados em poemas e tragédias, mas ficaram anônimos porque não foram hineados por poetas (poietôn) e por fazedores de discursos (logopoiôn) (136-137).

Isso não quer dizer simplesmente identificar ser e parecer, virtude e reputação, porém determinar critérios de valor diferenciados, mas que devem estar correlacionados. Dessa maneira, ele esclarece que o eudokimeîn, o ser bem estimado pelo corpo de cidadãos, está na dependência tanto das ações do si mesmo, quanto dos discursos daqueles que se preparam e são conformados naturalmente para isso, como os poetas. O não cumprimento de uma dessas duas condições redunda no fracasso do cidadão que ambiciona ou se situa em uma posição ou função importante no quadro da pólis, como foi o caso de um de seus melhores discípulos, Timóteo. Embora tenha sido ele, segundo a visão de Isócrates, um chefe militar exemplar e um excelente administrador dos negócios da pólis, não soube, todavia, defender e manter a sua reputação entre os seus concidadãos. Se Timóteo foi condenado numa ação judicial no final de sua carreira, ainda que isso pudesse se diagnosticar como uma injustiça face às suas meritórias e renomadas ações no passado, tal fato se deveria à sua inabilidade para captar a benevolência (eúnoia) do público. Dito de outra forma, não houve discursos que referendassem as suas ações e mantivessem a sua reputação no escopo da boa dóxa. Não obstante, Isócrates leva a cargo $a$ posteriori essa tarefa e faz uma retrospectiva encomiástica dos feitos e do modo de vida do seu discípulo. Está em questão a dóxa de seu discípulo post mortem; é aqui que este escritor quer mostrar a sua perícia nos discursos: transformar a má dóxa em boa fama através do discurso acerca de um bíos. Vejamos a passagem em causa:

Isso tem lá sua razão: enquanto aqueles tratam com solicitude os oradores (em espaços públicos) e os capazes de fabricar discursos (logopoieîn) em reuniões privadas, os quais fazem de conta conhecer tudo, você (Timóteo), por tua parte, não apenas negligencia, mas inclusive sempre entra em disputa com os que são mais habilidosos entre eles. Todavia acredita você quantos, por causa das difamações daqueles, terem uns caído em desgraça, outros privados dos direitos políticos, e quantos dos antepassados (você crê) terem ficado desconhecidos, mesmo sendo de maior quilate e mais dignos de mérito do que os que foram celebrados em cantos e tragédias? Uns [os que se tornaram famosos], creio, nesse caso, calharam de encontrar poetas e fabricadores

Revista Letras,

Curitiba, UFPR,

n. 97 , pp. 8-37,

jan./jun. 2018.

ISSN 2236-0999

(versão eletrônica) 
de discurso, enquanto outros [os que ficaram anônimos] não tiveram quem os celebrasse. Se então você se deixar persuadir por mim e tiver isso em mente, não menosprezará esse tipo de homens, em que a massa costuma depositar sua confiança não apenas acerca de cada um dos cidadãos tomados isoladamente, mas também acerca de todas as questões e negócios; você, não obstante, tratará deles com o devido cuidado e solicitude, para que alcance uma reputação em vista de ambos os aspectos: em função de teus próprios feitos e em função dos discursos daqueles. (Isócrates, Sobre a troca, 136-137; tradução nossa)

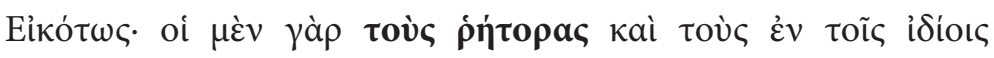

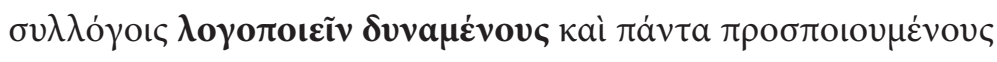

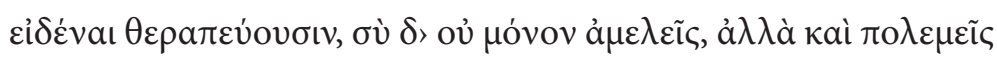

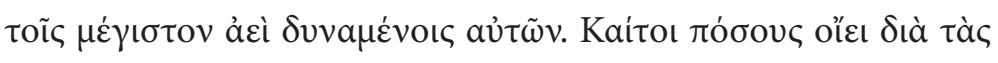

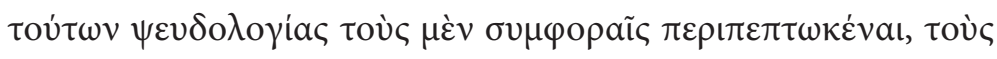

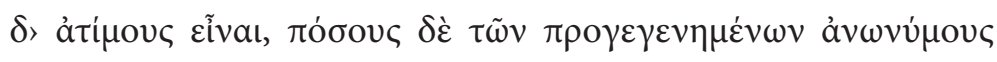

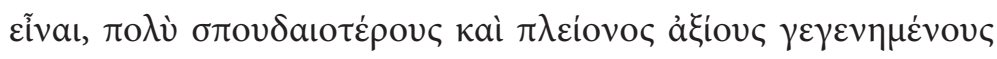

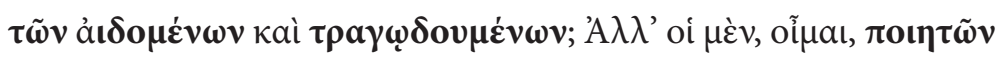

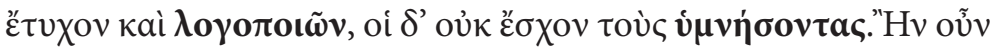

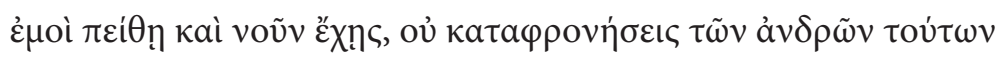

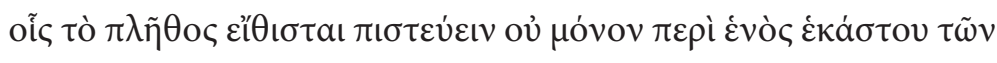

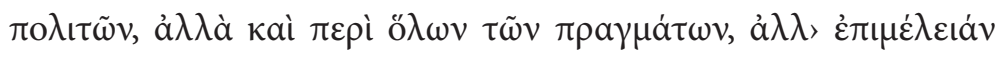

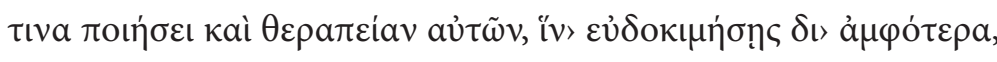

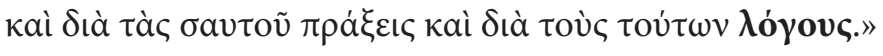

Como a atestação de discípulos virtuosos, cujas ações beneficiaram a pólis, é apresentada como um argumento crucial a favor da conduta de Isócrates e como, a despeito disso, o desempenho político de Timóteo tinha sido considerado, de certo modo, um malogro, então ele sente a necessidade de alongar os comentários sobre esse discípulo, compondo um pequeno lógos sobre o seu bíos ${ }^{11}$. Enquanto em relação ao cuidado dos negócios externos (tèn tôn pragmáton epiméleian) era deinós, perito e experiente, no que tangia ao tratamento dispensado aos homens que compunham a pólis (tèn tôn anthrópon therapeían), ele se revelava como naturalmente incapacitado (aphyés)(131). Assim, ao cuidado continuado com as próprias ações e com o modo de vida que caracteriza o bíos é imprescindível um cuidado com o lógos, um esforço contínuo para manter ante a coletividade a boa fama através de discursos, de um lógos sobre o bíos de outrem ou de si mesmo. Carecendo, com efeito, de tal lógos, de

11 Narra, a princípio, os vários sucessos de Timóteo como general nas expedições de guerra encetadas por Atenas. Caracteriza-o como deinós na arte militar, mas enfatiza sua qualidade de phrónimos, de possuir uma inteligência prática para dirimir questões, assim como para reconhecer contra quem se deve fazer a guerra e a quem se aliar (117). Assim, ele demonstrava para com a pólis e as outras cidades gregas um cuidado (epiméleian) (124), um tratamento e uma atenção continuada. Esse cuidado, no entanto, foi o que lhe faltou na esfera da política interna concernente a Atenas. 
IPIRANGA JR, P.;

Fischer, L. G.

A prosa em

face do discurso

poético em

Isócrates

Revista Letras,

Curitiba, UFPR,

n. 97 , pp. 8-37,

jan./jun. 2018.

ISSN 2236-0999

(versão eletrônica) poetas ou de fabricantes de discursos que tomassem esse encargo, o discípulo de Isócrates teria sido condenado por uma má dóxa e malogrado politicamente ${ }^{12}$. $\mathrm{O}$ parâmetro de comparação que Isócrates encontra, fora uma analogia formal com procedimentos estéticos e figuras de estilo, baseia-se na capacidade encomiástica de sua prosa, o que a tornaria, segundo ele, bem mais bela, porque mais proveitosa para a pólis, do que a obra poética de Píndaro $(166)^{13}$. Que a narrativa do bíos feita por Isócrates não seja um relato da vida privada é o que nosso prosador faz questão de enfatizar: essa experiência biográfica acerca do si mesmo, enquanto foro do debate político de alguém que delibera consigo próprio, diz respeito à constituição de si como agente moral, que se realiza como um treino e um cultivo de si nos discursos, com o fim de preparar-se para a efetiva arena política; no caso de Isócrates, essa efetivação já se faz pela escrita e publicação de suas obras ${ }^{14}$. Somado-se a isso, essa constituição desse tipo de bíos perpassa o campo do poético, caracterizado não como aquilo que Aristóteles, na Poética, definirá como mímesis, mas por aquilo de que ele fornece alguns elementos ao tratar do gênero epidítico na Retórica. A questão, reiteradamente discutida por Isócrates, diz respeito ao louvor ${ }^{15}$, o que é mencionado no primeiro livro desta obra de Aristóteles, mas não sistematicamente teorizado dentro do quadro dos gêneros retóricos.

Com efeito, a finalidade de quem se torna digno de louvor louvando (como Isócrates se arroga) busca, num primeiro momento, apresentar a si como confiável, mas, a partir daí, sobretudo, constituir o seu caráter, em tal discurso encomiástico, enquanto pístis, um convencimento que ocupa o segundo lugar na teorização aristotélica e o primeiro na argumentação de Isócrates. Segundo temos verificado, essa concepção do ser digno de louvor louvando é associada por Isócrates à qualidade de seu próprio discurso, portador de uma dýnamis poética, pois ele louva pelo lógos

12 Por seu turno, em relação ao bíos de Isócrates, a epiméleia está vinculada ao escopo de um programa pedagógico. Ele próprio foi educado com um grande esmero e cuidado (epimelôs)(161); também o corpo, num programa educativo, igualmente exigiria exercícios, práticas e treinos contínuos (taîs d'empeiríais kaì tâ̂s epimeleíais)(191); aqueles que querem tornar a si mesmos melhores e mais virtuosos devem voltar a atenção para si e se ocupar em treinamentos de si próprios (tàs autôn epimeleías) naquilo em que desejam adquirir experiência e saber. Isso pressupõe exercícios (melétais) e esforços (philoponíais), com a finalidade de treinar e desenvolver o raciocínio e a ponderação (pròs tèn tês phronéseos áskesin (207-209)). Chega ele, por conseguinte, a fazer um estreito paralelo entre paidéia e epiméleia, declarando que uma e outra têm uma dýnamis, a qual, num certo sentido, proporciona um reconhecimento cada vez mais aprimorado de uma meta moral elevada: a epieíkeia (211-214). Nessa esfera da paidéia, apresenta ele e prescreve a epiméleia preferencialmente como o cultivo de si mesmo (autoû... tèn epiméleian)(290), assinalando que os que agem segundo esse cuidado e esse cultivo de si são dignos de ser elogiados (epaineîn) (250) e de adquirir uma boa reputação.

13 Segundo Momigliano (1991, p. 74-75), ele reclamava para a sua prosa, além da excelência moral, a prerrogativa, por excelência, da poesia: a de conferir imortalidade.

14 Para a relativização do caráter pragmático da filosofia de Isócrates e a manifestação de uma espécie de idealismo, cf. LEFF, 2004, 238-239.

15 Cf. ARISTÓTELES, Retórica, I, 9 [1366a]: Acontecerá, com efeito, aos que falam acerca dessas coisas [dos modos e das coisas que são visadas por aquele que elogia e por aquele que vitupera], de, ao mesmo tempo, também mostrarem aquelas, a partir das quais nós poderemos ser compreendidos e revelados conforme o caráter (katà tòn éthos), o que era a segunda forma de convencimento (pístis); pois, pelas mesmas coisas e procedimentos, poderemos tornar dignos de crédito tanto a nós mesmos, quanto a um outro, em relação à virtude (pròs aretén). 
o que Píndaro louvara pela poíesis. Esta passagem de Sobre a troca [166], abaixo citada, que faz uma tal alusão a Píndaro, pode ser relacionada com aquela anterior em que se comenta a necessidade de um lógos de louvor para a sustentação da fama dos grandes homens:

E ainda é mais espantoso que, se a Píndaro, o poeta, os da geração anterior à nossa, em função de um único dito, uma vez que chamou a cidade de "amparo da Grécia", de tal forma o honraram que o elegeram como próxeno e lhe ofereceram um presente de dez mil dracmas, a mim, contudo, que elaborei encômios em bem maior número e de melhor qualidade artística dedicados à cidade e a nossos antepassados, não me seja permitido terminar a vida em segurança no tempo que me resta. (Isócrates, Sobre a troca, 166, tradução nossa).

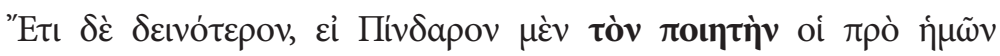

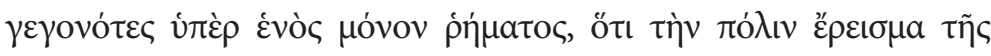

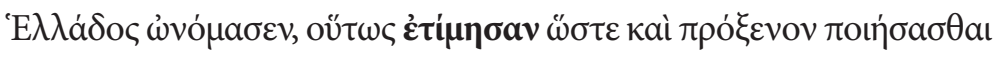

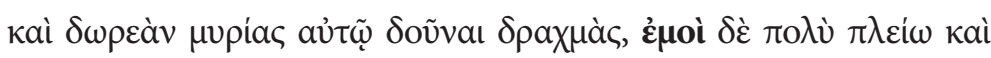

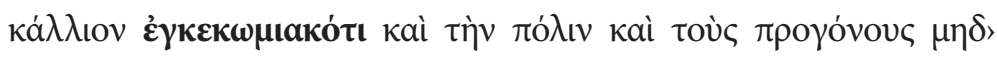

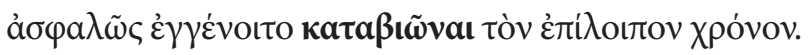

Logopoiós é a palavra escolhida por Isócrates para qualificar este tipo de prosador que, pelo seu louvor, faz com que os homens e seus feitos sejam celebrados e se tornem renomados. Embora queira ele ser recompensado pela pólis por sua ação de poieîn lógous em louvor dela (298), não chega a sistematizar essa ocupação de logopoiós numa noção mais precisa e aplicá-la a si próprio - porém, isso pode ser, de certo modo, depreendido pelo emprego (certamente disperso) de expressões correspondentes ao longo do relato ${ }^{16}$.

16 Em relação à questão do louvor, Aristóteles, por seu turno, ao se referir à emulação, explicita que homens são dignos de serem emulados, entre os quais estão "aqueles aos quais muitos querem ser semelhantes, ou dos quais muitos querem ser conhecidos ou amigos. Ou aqueles que muitos admiram ou os que eles mesmos admiram. E aqueles dos quais se dizem elogios e encômios (épainoi kai enkómia légontai) ou por poetas ou por escritores de discursos (hypò poietôn kai logográphon)" (ARISTÓTELES, Retórica, II, 12 [1388b]). Emprega aqui Aristóteles a palavra evitada por Isócrates, no caso, o termo logógrafo, para qualificar alguém que escreve uma prosa encomiástica e que se situaria no campo da retórica (termo que recebe uma conotação depreciativa, de fato, na prosa platônica (Cf. PLATÃO, Fedro, 257c). A expressão para prosa que aparece na Retórica, num paralelo e confronto com a poesia, é psilòs lógos, em que a contraposição se dá entre um discurso através de metros (a que é conveniente todo tipo de recurso e figura) e aquele que é desnudo deles (psilós), assim como da pletora de artifícios poéticos que o tornariam sem naturalidade. Embora deixe bem claro que a elocução da poesia, baseada nos metros, não é conveniente à prosa (no caso, a dos oradores), em todo o livro terceiro da Retórica o estilo do lógos retórico se constitui em paralelo e em confronto com o discurso poético. Na verdade, a prosa pode lançar mão de recursos poéticos de maneira controlada e oportunamente, mas o exagero em tal emprego ocasiona a impressão de o discurso ser fabricado e, assim, enganoso, o que certamente comprometeria sua finalidade de convencer os ouvintes. Nesse sentido, Górgias é sempre apresentado como paradigma de uma prosa não consciente de seus limites em sua tendência à léxis poética (ARISTÓTELES, Retórica, III, 1-2 [1404a-b]) 
IPIRANGA JR, P.;

Fischer, L. G.

A prosa em

face do discurso

poético em

Isócrates

\section{Evágoras: uma bela prosa útil}

Isócrates, em outra obra, discute as vantagens da poesia e a impossibilidade para a prosa de fazer uso de muitos recursos poéticos, tal como se pode observar nessa passagem do Evágoras:

[8] Eu sei que é difícil o que estou prestes a realizar, que é fazer um encômio em prosa à excelência de um homem. Eis a maior prova disso: aqueles que se dedicam à filosofia ousam falar de muitos assuntos de todo tipo, mas nunca nenhum deles tentou escrever a respeito de assuntos tais como esse. E em grande medida eu os compreendo. [9] Pois aos poetas são concedidos muitos adornos; de fato, lhes é possível fazer os deuses se aproximarem dos homens, conversarem e se aliarem a quem quiserem, e lhes é possível mostrar isso não só com as palavras estabelecidas, mas também com estrangeirismos, neologismos e metáforas, sem deixar nada de lado, mas ornando de todas as formas a poesia; [10] aos que se ocupam da prosa não é permitido nenhum desses recursos, mas é necessário usar com precisão dentre as palavras aquelas conhecidas do público e dentre as ideias aquelas que dizem respeito aos próprios fatos. Além disso, os poetas fazem todas as obras com metro e ritmo, mas os prosadores não tomam parte em nada disso, e essas obras têm tal encanto que, ainda que sejam mal feitas na dicção e nas ideias, por conta da harmonia e da simetria elas conduzem a alma dos ouvintes. reservasse as palavras e as ideias dos poemas célebres e desfizesse o metro, eles pareceriam muito inferiores à opinião que hoje temos deles. Contudo, ainda que a poesia tenha tantas vantagens, não se deve hesitar, mas é preciso testar os discursos (em prosa), e, se eles também forem capazes disso, elogiar os bons homens de modo nada inferior àqueles que compõem encômios em cantos e metro. (Evágoras, 8-11; tradução nossa, grifes nossos)

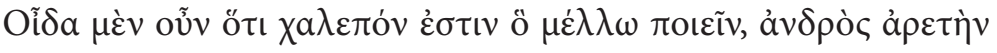

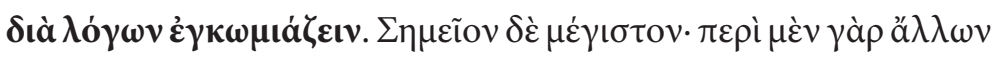

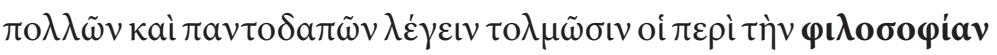

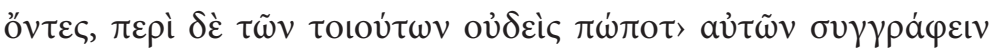

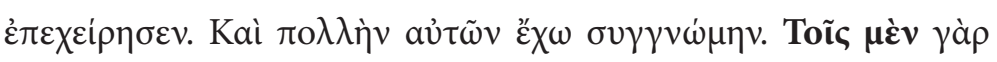

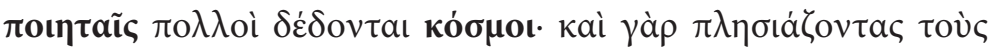

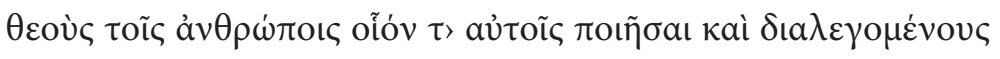

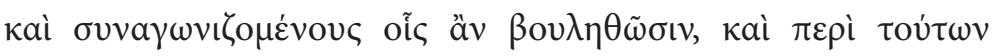

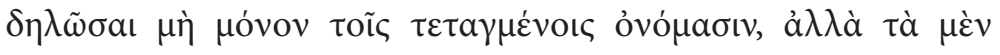

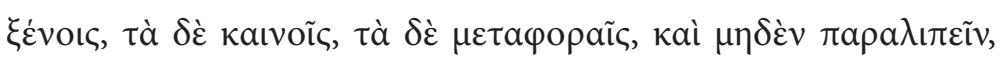

Revista Letras,

Curitiba, UFPR,

n. 97 , pp. 8-37,

jan./jun. 2018. ISSN 2236-0999

(versão eletrônica) 


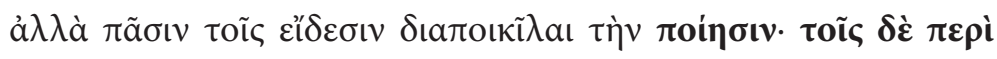

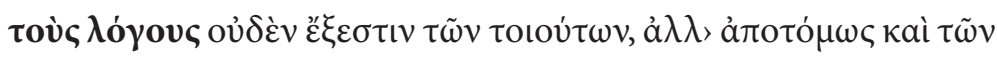

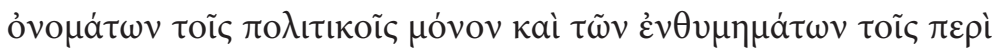

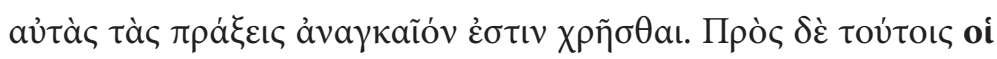

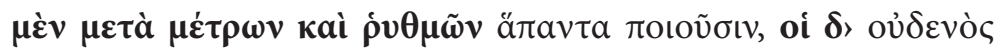

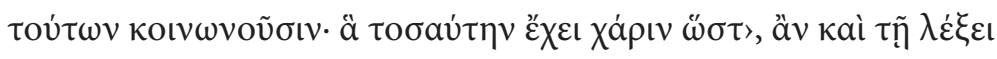

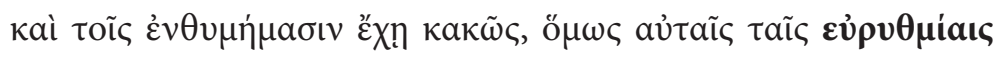

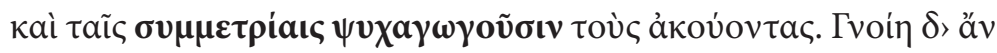

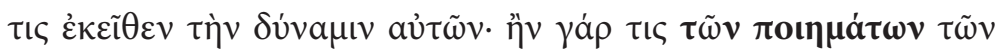

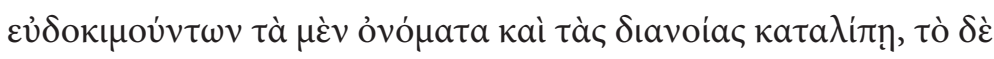

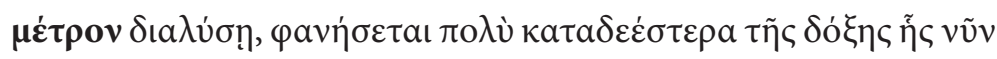

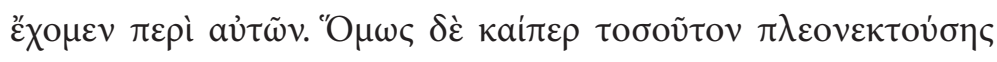

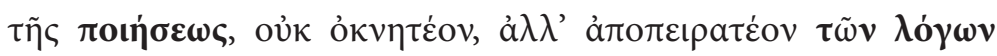

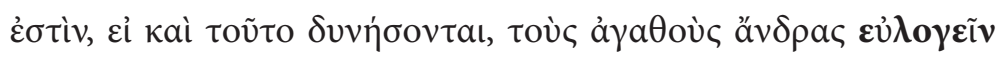

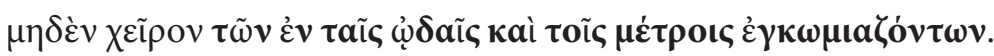

Essa obra consiste no encômio de Evágoras, falecido soberano de Chipre e pai de Nícocles, cujos feitos e personalidade o orador considera dignos de memória. Em Evágoras Isócrates realiza uma espécie de bela prosa útil, que cumpre ao mesmo tempo ideais artísticos e didáticos. Desde o proêmio, Isócrates anuncia seu projeto de "fazer um encômio em prosa à excelência de um homem" (Evágoras, 8), uma realização que o próprio orador apresenta como inédita. O contraponto evidente que ele quer estabelecer aqui é com o encômio poético, do qual podem ser tomados como exemplos os epinícios de Píndaro e Baquílides. Tudo isso opera aqui como um motivo de obstáculo, em que o orador explicita as dificuldades do que pretende fazer para tornar seus feitos mais valorosos e angariar a simpatia do público.

O movimento de aproximação de Isócrates à tradição poética nesse proêmio é explícito. O orador se propõe trazer para a prosa um gênero poético e se coloca na posição de emular a poesia afirmando: "ainda que a poesia tenha tantas vantagens, não se deve hesitar, mas é preciso testar os discursos, e se eles também forem capazes disso, elogiar os bons homens de modo nada inferior àqueles que compõem encômios em cantos e metro" (Evágoras, 11). Em A Nícocles, ainda que de modo mais sutil, Isócrates também se aproxima da tradição poética ao traçar paralelos entre os discursos exortativos e úteis e a poesia gnômica por um lado e os discursos agradáveis e a poesia de Homero e dos trágicos por outro, como argumentado anteriormente. Ao apresentar sua própria exortação em afinidade com a poesia de Hesíodo, Teógnis e Focílides, Isócrates sugere sua própria vinculação ao campo da tradição gnômica. Por conseguinte, de modo geral, as aproximações com a tradição poética são um tema recorrente na obra de Isócrates, pois ele vê nessa tradição um lugar de autoridade cultural ao qual ele pretende associar sua própria oratória.

Ainda quanto à classificação da obra como um encômio, cabe notar a distinção que Aristóteles (Ret. 1367b) traça entre encômio e elogio (épainos). Segundo o filósofo, o elogio trata da grandeza da areté enquanto o encômio trata das obras. Em Evágoras, 
IPIRANGA JR, P.;

Fischer, L. G.

A prosa em

face do discurso

poético em

Isócrates

contudo, Isócrates inverte a definição aristotélica e faz da areté o objeto do encômio. Mais propriamente o que se nota é que a obra de Isócrates trata justamente dos dois elementos, da virtude individual de Evágoras e de seus feitos admiráveis. Assim, Isócrates em duas partes ilustra o caráter de Evágoras para narrar seus feitos na sequência. Primeiro ele ilustra as virtudes de Evágoras entre a juventude e a vida adulta e em seguida conta seu exílio, regresso e ascensão ao poder (Evágoras, 22-32); num segundo momento ele descreve as qualidades de Evágoras como governante para depois relatar seus feitos administrativos e suas vitórias militares nas campanhas contra os lacedemônios e os persas (Evágoras, 40-64). A matéria histórica de seu relato também serve de instrumento de sua emulação frente à poesia, que trata de material mítico. Nesse sentido, Isócrates ressalta a importância de se compor o elogio entre aqueles que conhecem os fatos, utilizando a verdade a respeito da pessoa louvada (Evágoras 5). O argumento de se ater aos fatos conhecidos, inscrevendo o elogio nos limites da fiabilidade histórica, é recorrente no presente discurso, voltando a ser explicitado pelo orador quando ele decide deixar de lado de seu elogio os prodígios que teriam marcado o nascimento de Evágoras, para tornar evidente a todos que ele estava "longe de falar inventando coisas" (Evágoras, 21).

Apesar dessas alegações do orador, os fatos não são relatados com exatidão histórica. Van Hook (1945) observa que Isócrates opta por omitir os reveses sofridos por Evágoras em suas campanhas militares, narrando apenas seus sucessos. Além disso, acontecimentos como as circunstâncias da morte do soberano, assassinado em uma conspiração, são postos de fora do relato, por serem incondizentes com o tom laudatório pretendido. Nesse sentido, verifica-se que o orador adequa a matéria histórica aos fins de seu discurso. Tal procedimento não era estranho ao gênero epidítico, como observa Gillis (1971, p.55) a respeito do Panegírico do próprio Isócrates:

Esperava-se que os oradores epidíticos colorissem os fatos, e a audiência presumia que Isócrates operaria dentro dessa tradição. Não há nada que sugira que Isócrates considerava que isso fosse um engano intencional; isso, de fato, não interferia nem desfigurava o propósito ético e educacional do gênero epidítico, pelo contrário, o realçava. (Tradução nossa).

Para Isócrates, os feitos de Evágoras chegam a ser superiores aos dos heróis épicos, tornando o soberano merecedor de uma memória eterna, e a função de eternizar à memória tradicionalmente associada à poesia Isócrates busca associar à prosa. No começo de seu discurso ele sugere que "se o discurso narrar bem os feitos de Evágoras, tornará a excelência dele eternamente lembrada" (Evágoras, 4), explicitando a intenção de eternizar a memória por meio da prosa, além de se colocar no dever de narrar bem, visto que no epílogo ele afirma que as imagens dos atos e pensamentos "só se poderiam observar nos discursos que são artísticos" (Evágoras, 73). Assim, justamente para cumprir sua intenção, Isócrates afirma a necessidade da elaboração artística de sua obra. Isócrates não vê essa eternização da memória de Evágoras apenas como um fim em si, mas a considera capaz de se prestar a fins didáticos. Ele reconhece a importância de se elogiar os homens de seu

Revista Letras,

Curitiba, UFPR,

n. 97, pp. 8-37,

jan./jun. 2018.

ISSN 2236-0999

(versão eletrônica) 
próprio tempo como maneira de incentivar os mais jovens a se dedicarem ainda mais à virtude na busca de ganharem elogios ainda maiores que aqueles que eles escutam. Assim, a figura de Evágoras se transforma também em um modelo a ser imitado por aqueles que querem se tornar melhores. Essa função didática não deixa de ser outra vinculação à tradição poética, na qual os elogios e encômios de homens ilustres do passado ofereciam modelos de conduta para que os jovens imitassem com o fim de obter a virtude.

Nesse sentido, as qualidades de Evágoras elogiadas por Isócrates são também recomendadas pelo orador ao público. É significativo que quando Aristóteles argumenta em sua Retórica (1367b) que há uma semelhança entre o elogio e o conselho, bastando uma ligeira troca de palavras para se passar de um a outro, é justamente a seção 45 do Evágoras de Isócrates que ele cita como exemplo dessa transformação ${ }^{17}$. Portanto a própria leitura aristotélica reforça a interpretação exortativa desse encômio. Considerando-se a tripartição dos gêneros oratórios apresentada pelo próprio Aristóteles (Ret. 1358a), o Evágoras de Isócrates apresenta tanto elementos do gênero epidítico, ao desenvolver o elogio do falecido rei, quanto do gênero deliberativo, ao aconselhar Nícocles a seguir as virtudes elogiadas em seu pai.

No epílogo, o próprio Isócrates declara os fins protrépticos de seu encômio a Evágoras, ao reunir as virtudes do soberano e orná-las com o discurso, permitindo assim que Nícocles e seus descendentes as observem e se ocupem com elas. Segundo o orador, o elogio aos outros é justamente um modo de dirigir os homens à filosofia (protrépein epi tèn philosophían). Portanto, a própria composição de elogios é entendida por Isócrates como uma atividade filosófica, por causa da função protréptica do louvor às qualidades dos bons homens, capaz de dirigir os demais à filosofia e incitá-los ao cultivo do pensamento. Entendendo a filosofia professada por Isócrates como um exercício deliberativo orientado à prudência nas decisões políticas, nota-se que a figura de Evágoras é justamente apresentada como uma realização da filosofia isocrática.

Deve-se notar ainda que Isócrates concebia as capacidades de falar bem e pensar bem como naturalmente relacionadas, de modo que o treino discursivo seria capaz de aperfeiçoar a capacidade deliberativa (Sobre a Troca, 277). Isso implica que a filosofia isocrática tem o compromisso de garantir a efetiva realização artística do discurso, visto que apenas nessa realização seria possível encontrar a imagem dos pensamentos e ações da qual depende a função didática. Essa dependência, portanto, da filosofia para com a boa realização discursiva reforça a estrita relação que Isócrates concebe entre eloquência e reflexão. Disso resulta o entendimento

17 Cf. a passagem específica: "O elogio e os conselhos pertencem a uma espécie comum; pois o que se pode sugerir no conselho torna-se encômio quando se muda a forma da expressão. Quando, portanto, sabemos o que devemos fazer e como devemos ser, basta que, para estabelecer isso como conselho, se mude a forma da expressão e se dê a volta à frase; dizendo, por exemplo, que importa não nos orgulharmos do que devemos à fortuna, mas só do que devemos a nós mesmos. Dito assim, tem a força de um conselho; mas expresso como elogio, será: ele não se sente orgulhoso do que deve à fortuna, mas apenas do que deve a si próprio. De sorte que, quando quiseres elogiar, olha para o conselho que se poderá dar; e quando quiseres dar um conselho, olha para o que se pode elogiar" (Retórica, 1367b-1368a. Tradução de Alexandre Junior et al., 2006. Grifos nossos). 
IPIRANGA JR, P.;

FISCHER, L. G. A prosa em face do discurso poético em Isócrates

Revista Letras, Curitiba, UFPR, n. 97 , pp. 8-37, jan./jun. 2018. ISSN 2236-0999 (versão eletrônica) de Isócrates de que as figurações dos atos e pensamentos de Evágoras só seriam devidamente apreciáveis em um discurso bem realizado artisticamente. Assim, Isócrates faz de seu encômio a Evágoras um discurso que reúne propósitos artísticos e didáticos. A consciência da grandeza de sua matéria histórica, a aspiração à inovação e à boa narrativa, bem como a emulação da poesia garantem o efeito artístico dessa obra. E, para o orador, esse trabalho artístico sobre o elogio seria a melhor forma de apresentar os feitos e pensamentos do soberano como um exemplo de virtude a ser emulado. Como resultado, Evágoras pode ser considerado uma realização do modelo de bela prosa útil estimado por Isócrates, em que a própria beleza do discurso opera como instrumento de aconselhamento.

Sem poder nos estendermos nos comentários sobre o Evágoras, gostaríamos de frisar os aspectos principais aqui retomados: 1) os grandes recursos que capacitam os poemas a agradar e seduzir os ouvintes podem ser emulados, senão sobrepujados, por um discurso em prosa; 2) busca- se uma paridade em efeitos estéticos entre prosa e poesia; 3) o encômio em prosa de enquadramento biográfico é agenciador dessa equipação entre prosa e poesia; 4) o caráter pedagógico e formativo desse discurso testemunha a utilidade, aqui estando salientado o benefício à polis, e, por conseguinte, o maior préstimo desse tipo de discurso; 5) a concepção de filosofia está estreitamente vinculada à forma em que o discurso é expresso.

Para uma noção comparativa dos vários termos e expressões adotadas por Isócrates que exemplificam os paralelos e comparações entre discurso poético e em prosa, eis o quadro abaixo ${ }^{18}$ :

\section{Quadro 1:}

1) Isócrates, A Nícocles, 2-3; trad. de Julio de Figueiredo Lopes Rego, grifos nossos: Julgo que seria a mais bela dádiva, a mais proveitosa e a mais apropriada para te dar e para tu receberes, se conseguisse determinar para quais ocupações te inclinando e de quais tarefas te afastando poderias administrar da melhor maneira possível a tua cidade e a tua realeza. $\mathrm{O}$ cidadão comum conta com muito que contribui para a sua educação: antes de tudo, ter uma vida sem luxos e ser forçado a deliberar dia a dia acerca de sua própria sobrevivência. Depois, as leis que balizam a vida política de cada um, a liberdade de expressão e a possibilidade de, por causa dos erros que cometeram aqui e ali, a olhos vistos reprovar aos amigos e atacar às claras os inimigos. Por fim, alguns dos antigos poetas lhe legaram conjuntos de conselhos sobre como viver a contento. Graças a tudo isso, é verossímel que o cidadão comum esteja melhor.

18 Para verificar um cotejo entre Platão e Isócrates e proporcionar uma corroboração desse modo de tratamento sobre o estatuto da prosa na Antiguidade a partir de uma correlação conscientemente buscada com o discurso poético, cf. IPIRANGA JÚNIOR, 2016, p. 85-106. 
2) A Nícocles, 7; tradução nossa: Se então tal presente/dádiva, uma vez confeccionado, será digno do assunto, é difícil saber desde o início; com efeito, muitas das composições poéticas com metro e das composições escritas em prosa (tôn metà métrou poiemáton kai tôn katalogáden syngrammáton), ainda estando no pensamento dos compositores, proporcionavam grandes expectativas, mas, uma vez terminadas e apresentadas aos outros, alcançaram uma reputação bem inferior ao que se esperava.

3) A Nícocles, 12-13; trad. de Julio de Figueiredo Lopes Rego, grifos nossos: (...) tem em mente que a educação e o empenho podem melhorar a nossa natureza e, dentre os que estiverem mais próximos de ti, aproxima-te dos mais prudentes. Os demais, se puderes, manda vir até ti. Julga que não deves ignorar nenhum dos poetas célebres, tampouco nenhum dos sofistas, mas, pelo contrário, sê espectador (ouvinte) dos primeiros e um estudante dos segundos. Prepara-te para ser crítico dos teus inferiores, mas um oponente dos teus superiores. Mediante tais atividades rapidamente te tornarás tal como imaginamos ser um rei que governa a cidade com retidão e que a administra com adequação.

4) A Nícocles, 42-44; trad. de Julio de Figueiredo Lopes Rego, grifos nossos: Dado que para mim está claro que todos julgam de muitíssima serventia os conselhos de poetas e prosadores (advindos de poemas e de composições em prosa), os homens, entretanto, não os escutam com prazer e reagem como quem é repreendido e, muito embora elogiem esses autores, a bem da verdade, preferem estar junto de quem cometeu os mesmos erros que cometeram, e não daqueles que das falhas os afastam. A poesia de Hesíodo, Teógnis e Focílides poderia ser dada como prova disso: dizem, com efeito, que esses são os melhores conselheiros para a vida dos homens, mas, conquanto afirmem isso, preferem se ocupar antes com os seus próprios disparates do que com os conselhos deles. Se alguém selecionasse as chamadas máximas dos poetas eminentes nas quais mais se esforçaram, ao fim comportar-se-iam do mesmo modo diante delas: para essas pessoas, seria mais prazeroso escutar a pior comédia do que as obras compostas da maneira mais engenhosa.

5) A Nícocles, 48-49; trad. de Julio de Figueiredo Lopes Rego, grifos nossos: Por causa disso está patente que quem desejar compor ou escrever algo atraente para a massa deve descartar os discursos mais proveitosos e selecionar os mais fabulosos, pois lhes agrada tanto ouvir tais coisas quanto assistir a combates e contendas. Por isso, também a poesia de Homero e dos primeiros inventores da tragédia é admirável: ao analisar a natureza humana, utilizaram ambas as formas em seus poemas (em sua poesia). Um narrou as fábulas dos conflitos e contendas dos semideuses, os outros, por sua vez, transformaram as fábulas em conflitos e feitos que não só são escutados, mas também vistos por nós. Portanto, partindo de 
IPIRANGA JR, P.;

Fischer, L. G. A prosa em face do discurso poético em Isócrates

Revista Letras, Curitiba, UFPR, n. 97, pp. 8-37, jan./jun. 2018. ISSN 2236-0999 (versão eletrônica) tais exemplos, está demonstrado que os que anseiam seduzir os ouvintes devem se afastar da reflexão e do conselho, e, em vez disso, falar daquelas coisas com as quais a multidão terá prazer.

6) Isócrates, Sobre a troca, 45-47; tradução nossa: Primeiramente, então, é preciso vocês perceberem isso: que os diferentes tipos de discurso (em prosa) não são menos numerosos do que aqueles dos poemas metrificados. Com efeito, certos prosadores gastaram sua vida investigando as genealogias dos deuses, outros comentaram filosoficamente sobre os poetas, outros quiseram recolher e reunir as ações ocorridas nas guerras e outros mais se ocuparam do gênero relativo a perguntas e respostas, os versados no método contestativo. Seria não pequena tarefa se eu tentasse enumerar todas as espécies de discursos; fazendo menção, contudo, àquela que então me é conveniente, deixarei de lado as outras. Com efeito, existem aqueles que, sem serem desprovidos de experiência nos tipos de prosa anteriormente ditos, preferiram escrever discursos, não sobre os contratos efetuados entre vocês, mas discursos de caráter helênico, político e panegírico, discursos que todos diriam ser mais semelhantes àquelas composições acompanhadas de música e ritmos do que àqueles enunciados nos tribunais. Estes discursos inclusive através de uma dicção/ estilo mais poético e variegado apresentam as ações, e buscam se utilizar de argumentos mais pomposos e inovadores, ademais organiza o discurso como um todo através de diversas formas/temas/estruturas notáveis e numerosas. Com esses tipos de prosadores, todos os ouvintes se alegram não menos do que com os poetizadores em obras com metro, e muitos inclusive desejam se tornar deles discípulos, considerando que os mais notáveis entre eles serem muitos mais sábios, melhores e mais capazes de trazer benefícios do que aqueles que fazem bons discursos para os pleitos.

7) Sobre a troca, 136-137; tradução nossa: Isso tem lá sua razão: enquanto aqueles tratam com solicitude os oradores (em espaços públicos) e os capazes de fabricar discursos (logopoieîn) em reuniões privadas, os quais fazem de conta conhecer tudo, você (Timóteo), por tua parte, não apenas negligencia, mas inclusive sempre entra em disputa com os que são mais habilidosos entre eles. Todavia acredita você quantos, por causa das calúnias/difamações daqueles, terem uns caído em desgraça, outros privados dos direitos políticos, e quantos dos antepassados (você crê) terem ficado desconhecidos, mesmo sendo de maior quilate e mais dignos de mérito do que os que foram celebrados em cantos e tragédias? Uns [os que se tornaram famosos], creio, nesse caso, calharam de encontrar poetas e fabricadores de discurso, enquanto outros [os que ficaram anônimos] não tiveram quem os celebrasse. Se então você se deixar persuadir por mim e tiver isso em mente, não menosprezará esse tipo de homens, em 
que a massa costuma depositar sua confiança não apenas acerca de cada um dos cidadãos tomados isoladamente, mas também acerca de todas as questões/negócios; você, não obstante, tratará deles com o devido cuidado e solicitude, para que alcance uma reputação em vista de ambos os aspectos: em função de teus próprios feitos e em função dos discursos daqueles.

8) Sobre a troca, 166; tradução nossa: E ainda é mais espantoso que, se a Píndaro, o poeta, os da geração anterior à nossa, em função de um único dito, uma vez que chamou a cidade de "amparo da Grécia", de tal forma o honraram que o elegeram como próxeno e lhe ofereceram um presente de dez mil dracmas, a mim, contudo, que elaborei encômios em bem maior número e de melhor qualidade artística dedicados à cidade e a nossos antepassados, não me seja permitido terminar minha vida em segurança no tempo que me resta.

9) Sobre a troca, 192; tradução nossa: Acerca, portanto, da natureza e da experiência sei tais argumentos. Acerca da educação não posso enunciar um discurso dessa espécie, pois não possui capacidade/efetividade nem semelhante nem aproximada a esses campos (natureza e experiência). Com efeito, se um discípulo acompanhar todas as lições concernentes aos discursos e as tratar com cuidado, examinando minuciosamente e com mais circunspecção do que os outros, calharia de ser um poeta dos discursos, mais habilidoso que a maioria; porém, ao apresentar-se diante da turba, se carecer disto apenas: de atitude resoluta e corajosa, não conseguiria enunciar coisa alguma.

10) Evágoras, 8-11; tradução nossa: Eu sei que é difícil o que estou prestes a realizar, que é fazer um encômio em prosa à excelência de um homem. Eis a maior prova disso: aqueles que se dedicam à filosofia ousam falar sobre muitos assuntos de todo tipo, mas nunca nenhum deles tentou escrever a respeito de assuntos tais como esse. E em grande medida eu os compreendo. Pois aos poetas são concedidos muitos adornos; de fato, lhes é possível fazer os deuses se aproximarem dos homens, conversarem e se aliarem a quem quiserem, e lhes é possível mostrar isso não só com as palavras estabelecidas, mas também com estrangeirismos, neologismos e metáforas, sem deixar nada de lado, mas ornando de todas as formas a poesia; aos que se ocupam da prosa não é permitido nenhum desses recursos, mas é necessário usar com precisão dentre as palavras aquelas conhecidas do público e dentre as ideias aquelas que dizem respeito aos próprios fatos. Além disso, os poetas fazem todas as obras com metro e ritmo, mas os prosadores não tomam parte em nada disso, e essas obras têm tal encanto que, ainda que sejam mal feitas na dicção e nas ideias, por conta da harmonia e da simetria elas conduzem a alma dos ouvintes. Alguém poderia saber a força delas a partir disto: pois se alguém reservasse as palavras e as ideias 
IPIRANGA JR, P.;

Fischer, L. G. A prosa em face do discurso poético em Isócrates

dos poemas célebres e desfizesse o metro, eles pareceriam muito inferiores à opinião que hoje temos deles. Contudo, ainda que a poesia tenha tantas vantagens, não se deve hesitar, mas é preciso testar os discursos (em prosa), e se eles também forem capazes disso, elogiar os bons homens de modo nada inferior àqueles que compõem encômios em cantos e metro.

11) Evágoras, 36; tradução nossa: Certamente, dos antigos regressos os mais célebres são aqueles que ouvimos pelos poetas; pois eles não só nos anunciam os mais belos dentre os que aconteceram mas também compõem novos além desses. Contudo, nenhum deles fez uma fábula/ mito de alguém que tenha voltado à sua pátria enfrentando perigos tão terríveis e assustadores; mas da maioria se conta que tomaram o poder por acaso, e dos outros que superaram seus inimigos com dolo e artifício.

12) Evágoras, 40; tradução nossa: Se então ele se destacasse em coisas pequenas, também lhe conviria ser digno de tais discursos; mas todos concordariam que a soberania é, dos bens divinos e humanos, o maior, mais venerável e mais disputado. E a esse que melhor obteve o melhor dos bens, qual orador, poeta ou prosador faria louvor digno de seus feitos?

13) Evágoras, 65-66; tradução nossa: Por certo, como alguém demonstraria a coragem, a prudência ou toda a excelência de Evágoras de maneira mais clara que através desses trabalhos e empresas arriscadas? Pois será evidente que ele não só superou as outras guerras, mas até mesmo aquela dos herois, que é celebrada em hinos por todos os homens. Pois estes com a Grécia inteira tomaram somente Troia, mas ele, possuindo apenas uma cidade, guerreou contra a Ásia inteira, de modo que, se os que quisessem fazer encômios a ele fossem tantos quantos são os que fazem aos herois, ele adquiriria fama muito maior que esses. De fato, quem encontraremos entre os que então viveram, se pondo os mitos de lado investigarmos a verdade, que tenha realizado tais feitos ou que tenha sido responsável por tantas mudanças nas circunstâncias políticas?

14) Evágoras, 72; tradução nossa: De modo que, se alguns dos poetas têm usado de exageros acerca de algum dos que viveram antigamente, falando que esse era um deus entre os homens ou uma divindade, mas não um mortal, conviria sobretudo que todas as coisas desse tipo fossem ditas acerca da natureza de Evágoras.

15) Evágoras, 73; tradução nossa: Então, daquilo que concerne a Evágoras, considero ter deixado muitas coisas de lado; de fato careço do auge de minhas forças, com o qual eu elaboraria com mais exatidão e empenho esse louvor; contudo mesmo agora, na medida de minhas forças, ele não está desprovido de um encômio. Eu, ó Nícocles, considero que também

Revista Letras,

Curitiba, UFPR,

n. 97, pp. 8-37,

jan./jun. 2018. ISSN 2236-0999

(versão eletrônica) 
são belos monumentos as imagens dos corpos, porém que são muito mais valorosas aquelas dos atos e do pensamento, as quais só se poderia observar nos discursos que são artísticos.

16) Evágoras, 76; tradução nossa: E por causa disso ainda mais eu tentei escrever esse discurso, considerando que essa seria a mais bela exortação para ti, teus filhos e todos os descendentes de Evágoras, se alguém, reunindo as virtudes dele e as ornando com o discurso, permitisse a vós observá-las e ocupar-vos com elas.

\section{Conclusão}

De uma forma ou de outra, a prosa gráfica isocrática tanto se arroga um status de discurso poético, quanto está engajada num programa eminentemente pedagógico e político. Vislumbra-se, ademais, uma abordagem que tangencia uma espécie de teorização acerca da prosa ${ }^{19}$, baseada num princípio encomiástico aplicado ao relato de um bíos, em vista de que se buscam paralelos e contrastes com as obras dos poetas, assim como com a finalidade do discurso poético e os efeitos que lhe são correlatos. A narrativa de uma vida, a exemplo de Evágoras e Sobre a troca ou de princípios para a vida, como acontece em A Nícocles, foi o gênero discursivo encontrado por Isócrates o mais fecundo, o mais conveniente e o mais flexível para abordar temas de caráter moral e político, com uma finalidade cognitivo-pedagógica e dotado de uma forma artística tal a concorrer com as obras dos poetas. Além disso, a correlação com o discurso poético de um modo geral se constitui como uma das formas mais precípuas para abordar e explicitar o estatuto da prosa na Antiguidade, a partir de parâmetros estéticos afins à poesia, mas cuja configuração artística teria de abarcar uma finalidade de caráter moral segundo a agenda política do autor, através de um treinamento pelos discursos.

19 Uma análise mais extensiva do conjunto das obras de Isócrates poderia chegar a resultados mais concludentes sobre a possibilidade dessa, por assim dizer, prosaica ou poética da prosa, o que certamente extrapola o escopo deste nosso estudo. 
IPIRANGA JR, P.;

Fischer, L. G. A prosa em face do discurso poético em Isócrates

Revista Letras, Curitiba, UfPR, n. 97 , pp. 8-37, jan./jun. 2018. ISSN 2236-0999 (versão eletrônica)

\section{Referências}

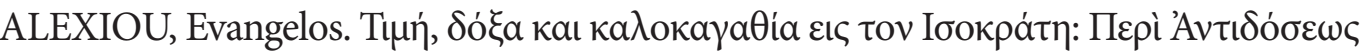

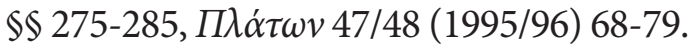

ARISTÓTELES. Retórica. Tradução de: ALEXANDRE JUNIOR, Manuel; ALBERTO, Paulo Farmhouse; PENA, Abel do Nascimento. 3a edição. Lisboa: Imprensa Nacional - Casa da Moeda, 20.

ARISTÓTELES, Poética. Tradução e notas de Ana Maria Valente. 2a. Ed. Prefácio de Maria Helena da Rocha Pereira. Lisboa: Fundação Calouste Gulbenkian, 2007. Retórica. Edición del texto con aparato crítico, traducción, prólogo y notas por Antonio Tovar. Madrid: Instituto de Estudios Politicos, 1953.

BELO, Fernando. Leituras de Aristóteles e de Nietzsche: A Poética Sobre a Verdade e a Mentira. Lisboa: Fundação Calouste Gulbenkian, 1994. GILLIS, Daniel. Isocrates' Panegyricus: The Rhetorical Texture. Wiener Studien, 84, pp. 52-73, 1971.

IPIRANGA JÚNIOR, P., STEPHAN, C., BUSE, Priscila. Carta a Nigrino. IN: Luciano de Samósata. Biografia literária. Organização Jacyntho Lins Brandão. Belo Horizonte: Editora UFMG, 2013, p. 40-54.

IPIRANGA JÚNIOR, Pedro. Prosa literária em face da poesia na Antiguidade: interlocuções de Luciano com o diálogo platônico. Organon (UFRGS), v. 31, n. 60, p. 85-106, 2016.

ISOCRATE. Discours. Tome II (Panégyrique - Plataïque - A Nicoclés - Nicoclés - Evagoras - Archidamas). Texte établi et traduit par George Mathieu et Émile Brémond. Paris: Les Belles Lettres, 1956.

ISOCRATES. Discourses. On the Peace, Aeropagiticus, Against the Sophists, Antidosis, Panathenaicus (V. II). Translation by George Norlin. Cambridge; Massachusetts; London: Harvard University Press, 1992.

ISOCRATES. Isocrates. Tradução de: NORLIN, George; VAN HOOK, Larue. Cambridge Mass: Harvard University Press, 1928-1945. 3v.

KENNEDY, G. A. “Isocrates' Encomium of Helen: A Panhellenic Document.” IN: Transactions of the American Philological Association, 89, p. 77-83, 1958.LÓPEZ, Silvia Aquino. Isocrates Logografo y Educador. IN: Cuadernos de Filosofia y Letras, n. 4, México, p. 70-92, 1985.

LEFF, Michael. Isocrates, Tradition, and the Rhetorical Version of Civic Education. IN: POULAKOS, T. \& DEPEW, D.. Isocrates and Civic Education. Austin: University of Texas Press, 2004. Project MUSE, https://muse.jhu.edu. Disponível em<https://muse.jhu. edu/book/2974>. Acesso em 21 de dezembro de 2017.

MATHIEU, George. Introduction. IN: ISOCRATE. Discours. Tome II (Panégyrique - Plataïque - A Nicoclés - Nicoclés - Evagoras - Archidamas). Texte établi et traduit par George Mathieu et Émile Brémond. Paris: Les Belles Lettres, 1950. MOMIGLIANO, Arnaldo. La Naissance de la Biographie en Grèce Ancienne. Tradução de Estelle Oudot, Strausbourg, Circé, 1991. 
MOUZE, Letícia. Educar o humano no homem: a obra estética e política do filósofo. IN: FROTEROTTA, Francesco \& BRISSON, Luc (orgs.). Platão: Leituras. Trad. João Carlos Nogueira; rev. Marcelo Perine. São Paulo: Edições Loyola, 2011, p. $179-186-78$.

OBER, Josiah. I, Socrates ... The Performative Audacity of Isocrates' Antidosis. IN: POULAKOS, T. \& DEPEW, D.. Isocrates and Civic Education. Austin: University of Texas Press, 2004. Project MUSE, https://muse.jhu.edu. Disponível em<https:// muse.jhu.edu/book/2974>. Acesso em 21 de dezembro de 2017.

PAPILLON, Terry L. Isocrates. IN: WORTHINGTON, Ian. (Ed.). A companion to Greek rhetoric. Malden; Oxford; Carlton: Blackwell Publishing, 2007, p. 58-74.

. Rhethoric, Art, and Myth: Isocrates and Busiris. IN: WOOTEN, Cecil W. (Ed.). The Orator in Action and Theory in Greece and Rome. Leiden; Boston; Köln: Brill, 2001, p. 73-96.

PAPILLON, Terry L. Isocrates and the Greek Poetic Tradition. Scholia 7, 1998, p. 41-61. URL: <http://www.otago.ac.nz/classics/scholiagfx/v07p041-061.pdf>, acessado em 08 de setembro de 2012.

PLATON. Fedro. Edicion Bilingüe, traduccion, notas y estudio preliminar por Luis Gil Fernandez. Madrid: Instituto de Estudios Políticos, 1970.

Gorgias. Texto Griego, Traduccion y notas de Julio Calonge Ruiz.

Madrid: Instituto de Estudios Politicos, 1951.

PLATÃO. Diálogos: Apologia de Sócrates-Critão-Menão-Hípias Maior e outros. Trad. de Carlos Alberto Nunes. Belém: Un. Federal do Pará, 1980.

. A República. Tradução e notas de Maria Helena da Rocha Pereira. Lisboa: Fund. Calouste Gulbenkian, 1990.

A República. Tradução, introdução e notas de Eleazar Magalhães Teixeira. Fortaleza: Edições UFC, Banco do Nordeste, 2009.

PERNOT, Laurent. La Rhetorique dans l'Antiquité. Paris: Librairie Générale Française, 2000. POULAKOS, Takis. Speaking for the Polis: Isocrates' Rhetorical Education. Columbia: University of South Carolina Press, 1997.

POULAKOS, T. \& DEPEW, D.. Isocrates and Civic Education. Austin: University of Texas Press, 2004. Project MUSE, https://muse.jhu.edu. Disponível em<https:// muse.jhu.edu/book/2974>. Acesso em 21 de dezembro de 2017.

RACE, WILLIAM H. Pindaric encomium and Isocrates' Evagoras. TAPA 137, pp. 131-55, 1987. REGO, Julio de Figueiredo Lopes. Os discursos cipriotas. para Demônico, para Nícocles, Nícocles e Evágoras de Isócrates, tradução, introdução e notas. Faculdade de Filosofia, Letras e Ciências Humanas da Usp. (Dissertação) São Paulo, 2010.

SCHIAPPA, Edward. The Beginnings of Rhetorical Theory in Classical Greece. New Haven\&London: Yale University Press, 1999. 
IPIRANGA JR, P.;

Fischer, L. G.

A prosa em

face do discurso

poético em

Isócrates
SZLEZÁK, Thomas. Leer a Platón. Versión española de José Luis García Rúa. Madrid: Alianza Editorial, 1997.

TEIXEIRA, Eleazar Magalhães. IN: PLATÃO. A República. Tradução, introdução e notas de Eleazar Magalhães Teixeira. Fortaleza: Edições UFC, Banco do Nordeste, 2009.

USHER, S. The style of Isocrates. BICS 20, pp. 39-67, 1973.

VAN HOOK, Larue. ISOCRATES. Isocrates. Tradução de: NORLIN, George; VAN HOOK, Larue. Cambridge Mass: Harvard University Press, 1928-1945. 3v.

Submetido em: 28/02/2018

Aceito em: 16/04/2018 